\title{
Eski Yakındoğu'da Göz Sembolizmi ve Düalizm: Mezopotamya, Mısır ve İsrail
}

\section{Eye Symbolism and Dualism in the Ancient Near East: Mesopotamia, Egypt and Israel}

\author{
Yeșim Dilek* (i)
}

*Öğr. Gör. Dr., Selçuk Üniversitesi, Yabancı Diller Yüksekokulu, Konya, Türkiye

\section{ORCID: Y.D. 0000-0003-0863-5468}

Sorumlu yazar/Corresponding author: Yeşim Dilek,

Selçuk Üniversitesi, Yabancı Diller Yüksekokulu, Konya, Türkiye

E-posta/E-mail: yesimdilek@selcuk.edu.tr

Başvuru/Submitted: 22.06 .2020 Revizyon Talebi/Revision Requested: 17.01.2021

Son Revizyon/Last Revision Received: 31.01.2021

Kabul/Accepted: 10.02 .2021

\section{Atıf/Citation:}

Dilek, Yesim. "Eski Yakındoğu'da Göz Sembolizmi ve Düalizm: Mezopotamya, Mısır ve İsrail." Tarih Dergisi - Turkish Journal of History, 74 (2021): 1-30. https://doi.org/10.26650/iutd.756209

\section{öz}

Antik Yakındoğu'da 'göz' kavramı canlıların görmesini sağlayan bir organ olmanın ötesinde çok farklı anlamlar ifade etmektedir. İyi ve kötü, ilahi ve şeytani, koruyucu ve yıkıcı gibi düalist güçlere sahip olduğuna inanılan göz, antik çağ insanının yaşamını şekillendiren dini hayatında oldukça önemli sembolik rollere sahip olmuştur. Göze yüklenen çift yönlü bu özellikler onu, o dönem insanının inançlarını yansıtan yazılı metin, heykel, ikonografi, kutsal obje, koruyucu muska ve dua gibi dini anlam içeren tüm eserlerde bir şekilde yer almasına neden olmuştur. Bilim ve teknoloji bilgisinden büyük ölçüde uzak olan bu toplumlar, her karşılaştıkları olağanüstü duruma sembolik bir anlam yükleme eğiliminde olmuşlardır ve dolayısıyla yaşam biçimlerini inançları doğrultusunda yönetmiş ve yönlendirmişlerdir. Bu toplumların yarattıkları ve anlam yükledikleri gözün sembolik çağrışımlarına bazı günümüz toplumlarında dahi inanılmaktadır. Gözün belirli güçlere sahip olduğuna duyulan inancın kökeni, Antik Mezopotamya, Mısır ve komşu bölgelerden İsrail'e kadar uzanmaktadır.

Anahtar sözcükler: Düalizm, Göz Sembolizmi, Kem Göz, İlahi Göz, Antik Yakındoğu

\section{ABSTRACT}

The concept of the 'eye' denotes much more in the ancient Near East than an organ that enabling sight in living creatures. The origin of the belief that the eye possesses certain powers originates from ancient Mesopotamia, Egypt, and regions neighboring Israel. The eye discharged key symbolic roles and was attributed dualist qualities in the spiritual existence of the ancient people: eyes could be good or evil, divine and or devilish, protective or destructive. The duplexity of features attached to the eye caused it to appear in nearly all significant religious works reflecting the beliefs of the people of that period including written texts, sculptures, iconography, sacred objects, amulets, and prayers. These early societies generally lacked scientific and technological knowledge and tended to accord symbolic meaning to all extraordinary phenomena they encountered. Their lives and beliefs were thus steered by their beliefs. The symbolic connotations devised for the eye, which these societies created and attached to. It persist in some present-day societies.

Keywords: Dualism, Eye Symbolism, Evil Eye, Divine Eye, Ancient Near East 


\section{Extended Abstract}

Dualism is both a religious and a philosophical doctrine that is measured by these two principles of the origin of the universe and the creative power of all beings. The phenomenon of dualism forms the building block of the beliefs and religious systems of some societies. Dualism describes polar distinctions such as good and evil, chaos and order, admiration and fear, or life and death, these binary particularities are critical elements for individuals who exist solely in accordance with their beliefs. The Mesopotamian and Levant societies are among the ancient Near East civilizations that most reflected dualism in their religious lives. The ancient Egyptian bidirectional view of was based on harmony and balance and was quite different from the other two civilizations mentioned above.

Ancient Egyptians learned from their lives and reasons for living to create balanced system that blended the good and the bad to achieve integrity that would lead them to the ultimate eternal goal. The conception of the numinous in these three civilizations can help to elucidate their divergent belief systems, lifestyles, and worldview issue. In turn, these differences can clarify their apprehensions of dualism and explain the dual features of the eye symbol. The significance of the notions of the evil eye and the divine protective eye in the Ancient Near East can thus be elucidated.

Scrutiny of sources expressing the phenomenon of dualism pertaining to the symbolism of the eye in the Ancient Near East societies clarifies that such a conception, which included the idea of the evil and the divine eye originated in these three early societies.

Certain norms mandated by the religious beliefs of ancient Mesopotamian societies, and the lifestyles of the people living in thesis region led to their perceptions of the universe to also be divided and demarcated with clear boundaries. These societies could not balance the good and the bad because of their beliefs and thus created a dualist reality constituted by their conception of the universe at its center. Assessing the symbolism of the eye enables the awareness that Mesopotamian society approached its symbolic value in a double-sided manner, focusing more on negative effects. Most experts, believe that the concept of the evil eye belief emerged from ancient Mesopotamia and spread to surrounding areas. Written documents and archaeological data reveal that the people of Sumer, who are believed to be the first inhabitants of the region, initiated, continued, and extended this belief.

According to Mesopotamian societies, the demons created by the sky god An represented the principal source of the evil eye because they caused all kinds of diabolic events. Thus, the evil eye was believed to cause diseases, famines, disasters, and other damage to human lives and livelihoods. Mesopotamians used magic, prayer, ritual, and most commonly, eye-shaped amulets to ward off or avoid the evil eye. The concept of the eye can also be associated with gods, even though this connection was uncommon in Ancient Mesopotamian societies where communities that accorded predominance to the negative aspect of the symbolic eye. The 
notion of the all-seeing and justice-meting eye was predominantly associated with the sky god, An; the moon god Nanna / Sin, sky gods such as the sun god Utu/ Šamaš, and Enlil, one of the most important gods of the pantheon,; and Marduk, the chief god of the Babylonian period.

The Egyptians perceived the universe differently from Mesopotamian society, Egyptians and thus focused more on the positive side of life evaluating all dualist approaches through harmony. They also emphasized the protective aspect of the symbolic eye Nonetheless, the existence of the evil eye belief in this society can be particularly understood through myths and iconographies. Horus myths and the use of the wedjat eye in the form of amulets most clearly evidence the existence of this belief. Like the Mesopotamians, the Egyptians believed the evil eye to threaten health, family, unity, and especially children. Like the Mesopotamians, they used prayers, spells, and amulets to ward off this evil power. The difference between the Egyptian conception of the evil eye and the Mesopotamian concerned the latter's belief that the evil eyes of human beings could also cause damage to others.

The relationship of the eye with the divine world can be observed most clearly in ancient Near Eastern civilizations in Egypt, in the idea of the protective eye. First, the eye was associated with the sun and the moon which were the most prominent celestial bodies of the sky. It attained its protective quality through this association, which was disseminated through varied versions of myths. Egyptian literature encompasses numerous eye-related narratives such as the escape and return of the eye goddess of Ra, the creation of human beings from the tears of the creator god, and the wounding of Horus' eye by Seth. The emergence of these stories and their connections with worldly life revealed the protective role and importance of the eye in ancient Egyptian society.

Distinct differences like those observed in Mesopotamia attract attention when the approach of the Israeli citizens to the religious dimension of dualism, is noted in which the period after the society converted to monotheism. The religious beliefs of the people of Israel are founded on the acceptance of Yahweh as the only God, and all religious developments are collected in the Old Testament along with the teachings. The dualism between good and evil is evident in the Old Testament, in which a single phenomenon is referenced as good, and a two-dimensional evil embodies sin. Good emanates firmly and directly from God. Conversely, evil is vested in the devil, who was created by God for certain reasons. Evil may also be sourced from the wicked ideas inherent in human beings.

The sacred values of Judaism do not allow visual representations. Hence, all inferences of eye symbolism must be based on the foundational text, the Old Testament. This holy book contains many positive and negative references to the symbolic features of the eye. First, this belief is evidenced in the assertion that the evil eye originates from as the negative emotions of people, for instance, mischief and jealousy. Moreover, the positive symbolic features attributed to the eye are used metaphorically in the Old Testament. Among these references is the divine eye that first sees, knows and represents justice as the eye of God. 


\section{Giriş}

Düalizm hem dini hem de felsefi bir doktrindir. Bu doktrin, evrenin kökeninin ve tüm var oluşların yaratıcı gücü olan bu iki prensiple ölçülür ${ }^{1}$. İnanç açısından ele alındığında ise 'düalizm' olgusu, bazı toplumların dini sistemlerinin yapı taşıdır. Düalizmde iyi ve kötü, kaos ve düzen, hayranlık ve korku, yaşam ve ölüm gibi keskin ayrımlar vardır ve bu ayrımlar, sadece inançları doğrultusunda yaşayan bireyler için oldukça önemli faktörlerdir. Düalizmin dini yaşamdaki yansımalarının en çok hissedildiği antik dönem Yakındoğu uygarlıkları arasında Mezopotamya ve Levant toplumları yer almaktadır. Mısır'daki çift yönlü hayat görüşü diğer ikisinden oldukça farklı olarak bir harmoni ve denge içerisindedir. Mısır halkının yaşamdan anladıkları ve hayattaki amaçları, iyi ve kötüyü harmanlayarak denge sistemini oluşturup nihai iyi bir hedef ve bütünlüğe ulaşmaktır.

Antik Yakındoğu'daki 'göz' sembolünün içerdiği çift yönlü özellikleri detaylandırmak için öncelikle kem göz ve koruyucu ilahi göz kavramlarının ne anlamlara geldiğinin açıklanması ve sonrasında bu üç medeniyetin birbirinden farklı düalizm anlayışına, inanç sistemine, yaşam tarzına, dünya görüşüne ve "numinous'² kavramının toplumlarındaki yansımalarına değinilmesi konuyu aydınlatmaya yardımcı olacaktır. Kem göz inancının yarattığı etkiye, kem gözden korunma yöntemlerine ve antik Yakındoğu'daki yayılım alanına bakıldığında çeşitli benzerlikler ve farklılıklar göze çarpmaktadır. Göz sembolizminin diğer bir boyutu olan ilahla bağlantılı olan koruyucu göz algısının bu üç toplumdaki yansımaları ise birbirlerinden oldukça farklıdır. Düalizm kapsamında bu konunun detaylı analizleri için Mezopotamya'dan başlamak üzere Mısır ve İsrail halklarının göz sembolizmine olan yaklaşımlarını ayrı ayrı ele almak gerekmektedir.

\section{A. Eski Yakındoğu'ya Düalist Yaklaşım}

\section{Mezopotamya}

Eski Mezopotamya'ya ait yazılı ve ikonografik veriler, Mezopotamya toplumlarının dini inançlarının korku ve hayranlık ile iyi ve kötü arasındaki net ayrıma dayandığını göstermektedir. Bu düalizm, o dönemde Mezopotamya'da yaşayan insanların hayatlarının her alanını etkileyerek, kaygı ve güvensizlik hisleri içerisinde var olmaya çalışmalarına sebep

1 Ugo Bianchi, "Dualism", ed. M. Eliade, The Encyclopedia of Religion, IV, Macmillan Publishing Company, New York 1987, s. 507.

2 “En açınmış haliyle Numinous duygu, sıradan 'ürperme' den çok farklı olsa da, en derin halinde bile türdeşi ile çelişmez. Ürpertene ibadet, zamanla tanrlara ibadete dönüşse de bu tanrlar, ibadet edenin duygularına etki eden, o ürpertici “Görünmelere dair bir Numina'yı” içermeye devam eder. Yani, ululuk ve yücelik niteliğine dönüşen ya da bu suretle sembolize edilen bir 'esrarengiz' ya da 'korkunç' niteliği hala vardır. Ne kadar yumuşatılmış olsa da, bu unsur, Tanrı'ya ibadetin en derin şeklinde bile yok olmuş değildir. Onun yok olması, çok temel bir öğenin devreden çıkması demek olurdu. O "ürperti”, en ulvi şekliyle her seferinde ortaya çıkar ve ruhun her yerine nüfuz eder.” Rudolf Otto, Kutsal'a Dair, Altıkırkbeş Yayınları, İstanbul 2014, s. 48. 
olmuştur. Tanrıların, doğanın yegâne numinous güçleri olarak algılandığı en eski dönemlerden başlayarak onların evrenin hükümdarları olarak görüldüğü ve kişisel tanrı fikrinin ortaya çıktığı döneme kadar geçen tüm süreçlerde korku ve hayranlık, iyi ve kötü arasındaki bu çift yönlü evren algısı toplumun yaşam biçimine hâkim olmuştur. Onlara göre, doğadaki tüm güçler ya olumlu ya da olumsuzdu. İnsanın yararına olan tüm doğaüstü müdahaleler, iyi ve yapıcı olarak algılanarak geliştirilmiş ve onlara tapınılmıştır. Aynı zamanda Mezopotamya toplumları net bir şekilde kötü güçlerin varlığına da inanarak bu negatif etkilerin kaçınılması, korkulması ve yok edilmesi gereken güçler olduğunu düşünmüşlerdir³.

Günümüz insanının bilimsel verilerle değerlendirebildiği tabiata dair her oluşumu Mezopotamyalılar ayrı bir doğaüstü güce yüklemek eğiliminde olmuşlardır. Kendilerine özgü nedensellik ilkelerine başvurarak hayatlarını yönlendiren, yaşamlarını belirleyen ve kültürlerini oluşturan natüristtik bir evren algısı geliştirmişlerdir. Bu algı, aslında ilkel dinlerde ve antik çağda yaygın ve egemen olan bir yaklaşımdır ${ }^{4}$. Doğa olaylarını bilimsel temellere oturtma yetisi bulunmayan Mezopotamyalılar doğa olaylarını anlaşılmaz, korkulan, gizemli, kontrol dış1, büyülü ve güçlü görmüşlerdir. Bu doğrultuda kendilerince bir inanç sistemi yaratmışlar ve tüm doğa olaylarını doğaüstü güçlerle tanımlamışlardır.

Durkheim, bu durumu 'tabiatçılık' olarak adlandırmış ve doğaya karşı duyulan hayranlık ve korku hislerinin yarattığı inanma dürtüsünü açıklamıştır. Bu dürtünün özünde insanın doğanın aşkınlığına ve görkemine karşı duyduğu hayranlığın yanı sıra hissetmekten kendisini alamadığ $\breve{1}$ belli bir etkinin varlığı söz konusudur. İnsan, öncelikle tabiatın kendisinden daha yüce olduğunu ve kendisini aştığını düşünmüştür ve böylece tabiat büyüklüğü ile insanı şaşırtmıştır ${ }^{5}$. Bu değerlendirme temel alınırsa, Mezopotamya toplumlarının inanç sistemi, düalizm anlayışı ve dünya algısı açıklanabilir.

Bottéro ve Kramer, Mezopotamya dini inancinı yorumlarken, "kutsal" ve "ulvi" kavramlarına değinerek, bunların insan zihninde iki duyguya yol açtığını belirtmişlerdir: "İnsan ya ondan korkar ve onunla karşı karşlya geldiğinde endişelenir ve hoşlanmaz; ya da onu çeker, ona hayran olur ve kendisine yaklaşmaya ihtiyaç duyar. Bütün dinlerin psikolojik kökenindeki inanç ve din duygusu, bu iki histen kaynaklanmaktadır." ${ }^{\circ} \mathrm{Bu}$ açıdan temel unsuru kutsaldan doğarak ortaya çıkan inanç, insanın yaşadığı iki farklı hissin birbirine geçmiş halinden doğan deneyimi yansıtan güçtür.

3 Thorkild Jacobsen, Karanlı̆̆ın Hazineleri, Paris Yayınları, çev. Sibel Erduman, İstanbul 2017, s. 25.

4 Kürşat Demirci, Eski Mezopotamya Dinlerine Giriş Tanrılar, Ritüel, Tapınak, Ayışı̆̆ı Kitapları, İstanbul 2013, s. 2 .

5 Emile Durkheim, Dini Hayatın İlkel Biçimleri, Ataç Yayınları, İstanbul 2005, s. 111.

6 Jean Bottéro - Samuel Noah Kramer, Mezopotamya Mitolojisi, çev. Alp Tümertekin, Türkiye İş Bankası Kültür Yayınları, İstanbul 2017, s. 56. 
Mezopotamya toplumları çoktanrılı bir inanışa sahiptirler. Tanrıları sonsuz, hayranlık uyandırıcı güçlere sahip doğaüstü varlıklar olarak görmüşlerdir. Bu insanlar, evrende mevcut olan tüm iyi durumları ve kötülüğün temsili olan demonları, doğal ya da doğaüstü tüm olayları kısaca her şeyi tanrıların yarattığına inanmışlardır. Böylece, Mezopotamya'da doğa olaylarına karşı aşkınlıktan dolayı hissedilen korku, güç, gizem, hayranlık vb. hisleri barındıran bir din yapısı ortaya çıkmıştır. Mezopotamya'da evrenin işleyişinde karşılaşılan her kavranamayan olayın bir yöneticisi olmuştur ve bu açıklanamaz durumlar otomatik olarak sayısız gücün hâkim olduğu bir sistemi de beraberinde getirmiştir.

Mezopotamya tanrılarının çoğu, çok yüksek bir mevkide ve insanoğlu ile mesafesi ulaşılmaz düzeyde olan, saygı duyulan, kutsal ve hayranlık uyandıran ama aynı zamanda çekinilip korkulan doğaüstü varlıklar olmuşlardır. Bölge halkı kendi nedensellik ilkeleri doğrultusunda tanrıları ve tecelli ettikleri gücü evrenin her yerinde görme eğilimi yaratmışlar ve böylece birçok ilahın varlığına inanmışlardır. Mezopotamyalılar, insanoğlunun, tanrılara hizmet etmek ve onları memnun etmek için yaratıldığı, kaosa sürüklenmeyen bir yaşam için onları sinirlendirmemeleri gerektiğini düşünmüşlerdir. Bu ikilemden Mezopotamya’nın esas olarak düalizmin olumsuz yönü ile yaşadığı anlaşılmaktadır. Bundan dolayı tüm kurallara uyarak, sonsuz sadakat ve kabullenişe bağlı eylemler de inançlarının temelini oluşturmuştur. Bu bağlamda, Mezopotamya toplumlarının göz simgesine yükledikleri anlam keskin çizgilerle iyi ya da kötü olmak üzere çift yönlüdür. Daha çok evrenin kötü yönüne odaklanan bu halk, kem göz kavramını hem yazılı metinlerinde hem de görsel sanatlarında vurgulamışlar ve sempati büyü kapsamında kem göze karşı koruyucu göz simgeleri geliştirmişlerdir?

\section{Misır}

Eski Mısır halkının dünya görüşü, evreni algılayış şekli, yaşam amacı, inanç sistemleri, numinous güçlerine bakış açısı ve elbette düalizmin çift yönlü gerçekliği Mezopotamya toplumlarınınkinden oldukça farklıdır.

Mısır toplumunun evrene ve var oluşa bakış açısı Mezopotamya toplumlarınkinden farklı olmasına rağmen, elbette tüm inanç sistemlerinde olduğu gibi bu dinin de kaynağında korku ve hayranlık yatmaktadır. Ancak buradaki çift yönlülüğü Mezopotamya'dakinden daha farklı bakış açıları ile değerlendirmek gerekmektedir. Örneğin; Mısır halkının yaşam biçimini ve dünya görüşünü aslında ironik bir şekilde ölümden sonraki ulaşmak istedikleri sonsuz ve gerçek yaşam belirlemiştir ${ }^{8}$. Mezopotamya'da ise ölüm algısı tamamen farklıdır;

7 Detaylı bilgi için bkz. Yeşim Dilek, Eski Mezopotamya Dini Ritüeller ve Kullanılan Objeler, Arkeoloji ve Sanat Yayınları, İstanbul 2019, s. 182-184.

8 Detaylı bilgi için bkz. Wallis Budge, Antik Mısır'da Ölüm Sonrası Yaşam ve Tanrılar, çev. Şebnem Duran, Lilith Yayıncılık, İzmir 2018; Erik Hornung, Kadim Mısır Ötedünya Kitaplarl, çev. Zehra Aksu Yılmazer, Kabalcı Yayınevi, İstanbul 2006; Geraldine Pinch, Misır Mitolojisi, çev. Ekin Duru, Say Yayınları, İstanbul 2019. 
ölüm sonrasında dünyada istenilen her görev yerine getirilse dahi gidilecek diğer âlemin yeryüzünün altında ve genellikle sıkıntı, keder, yokluk ve kasvetten oluşan yeryüzünün kötü bir yansıması olduğuna inanılmıştır9.

Mısır medeniyetinin en erken dönemlerinden itibaren var olan yeniden doğuş kavramı pek çok unsurda birlik fikrinin ortaya çıkmasına sebep olmuş olabilir. Güneş tanrısı Ra/ Horus'un ${ }^{10}$ batı ufkunda her gün yok olması, ölmesi olarak algılanmaktaydı, ancak ertesi gün tekrar ortaya çıkması da yeniden doğuşuydu. Bu durum Mısırlıların ölümden sonra mutlak yaşam olduğuna inandıkları düşüncesine bir kanıt teşkil etmektedir. Osiris ve Ra/Horus, aynı ilahi düzenin iki farklı yönünü yansıtırlardı; Osiris ölülerin tanrısı ve Ra/Horus yaşayanların baş tanrısıydı. Bu açıdan ikisinin uyumu 'birleşik ruh' olarak adlandırılmaktadır ${ }^{11}$. Bu bütünleşmiş ruh algısı, Mısırlıların dünyayı değişmeyen kararlılıkta dengelenmiş düalist bakış açısıyla algılama eğilimini ifade etmektedir ${ }^{12}$.

Eski Mısır'da iyi ve kötü arasındaki denge de aynı yaşam ve ölüm arasındaki uyuma benzer bir özellik göstermektedir. Bu toplumda iyi ve kötü arasındaki savaşı ve aynı zamanda uyumu yansıtan en belirgin kanıt Horus ve Seth arasında geçen ve pek çok farklı mitolojik öyküyü içeren anlatılardır. Bu iki tanrı ya kardeş ya da amca yeğen olarak betimlenmişlerdir. Aralarındaki bu uzlaşmazlığın kaynağının eski bir iç savaşa, firtınaya ya da astronomik olaya dayandığını iddia eden pek çok farklı varsayım yer almaktadır. Birinin gökyüzü şahini diğerinin ise fırtına tanrısı olmasından dolayı onların uzlaşmasının, karşıt unsurların bir araya getirerek ilahi düzeni oluşturdukları anlamına geldiği düşünülmektedir ${ }^{13}$. Özellikle Yeni Krallık döneminde Seth, fırtına tanrısı olarak güneş tanrısını ezeli düşmanından koruyan tanrı olarak ortaya çıkmıştır. Mısırlılar, Seth'in bünyesinde iyi ve kötü olmak üzere iki farklı karakter barındırdığına inanmışlardır. Watterson'ın, Mısır halkının Seth'in kötülük yapma potansiyelinden korktukları kadar gücüne ve gaddarlığına büyük hayranlık duyduklarını belirtmiştir ${ }^{14}$. Eski Mısır'ın geç dönemlerinde, Seth hem canavar yılanla hem de Işılk ve Karanlık arasındaki günlük savaşın başkahramanı ile ilişkilendirilmiştir ${ }^{15}$. Horus ve Seth arasında olan ya da her gece Ra'ya saldıran yılanla Seth arasında olan böyle bir savaştan galip çıkan olmadığı için hiçbir zaman nihai zafere ulaşılamaz. Döneme göre ilahların ismi ya da savaşları değişmekle birlikte, Mısır inancında iyiliği temsil eden ilahi güçler ile kötülüğü temsil eden ilahi güçlerin denge oluşturdukları ve düalizmin bütünleyici unsurları oldukları açıktır.

9 Dilek, a.g.e., s. 35.

10 Tüm kadim tanrılar gibi gökyüzü şahini Horus da yaratıcı güneş tanrısı ile ilişkilendirilmiştir. Pinch, Mısır Mitolojisi, s. 216.

11 Henri Frankfort, Kingship and the Gods, The University of Chicago Press, Chicago 1978, s. 211.

12 Frankfort, a.g.e., s. 19.

13 Pinch, a.g.e., s. 217.

14 Barbara Watterson, The Gods of Ancient Egypt, Batsford Ltd, London 1984, s. 116.

15 Wallis Budge, From Fetish to God in Ancient Egypt, Oxford University Press, London 1934, s. 141. 
Dini açıdan düalizm, Mısırlılar tarafından iki zıt unsurdan ziyade iki tamamlayıcı unsur olarak birliğin gelişimi şeklinde algılanmıştır ${ }^{16}$. Örneğin güneş ve ay, sağ ve sol göz, Yukarı ve Aşağı Mısır, tanrı ve kral, yaşam ve ölüm, 1şık ve karanlık, Horus ve Seth, Ma'at (düzen) ve İsfet (kaos) gibi zıt görünen kavramlar aslında Mısır'da bir bütünlük, denge ve birlik oluşturmuşlardır. Dahası bu toplum, evreni temelde statik olarak algılamış, oradaki değişimin, döngüsel bir değişim olduğuna inanmışlardır. Bu bağlamda bu topluma göre gece ve gündüzün oluşumu, sel ve kuraklık, mevsimlerin değişmesi ve yeniden aynı mevsimin döngüsel olarak gelmesi gibi yaradılış düzenini kuran değişken ve bütünleyici sistemler aslında 'evrenin ritmidir' ${ }^{17}$. Böyle bir inanç sisteminde ve evren algısında 'kötü' kavramı denge içerisinde mevcudiyetini gösterir ve sınırlandırılır. Bu açıdan evren, daimi denge içinde zıt güçleri barındıran ve kötülüğün Maat olarak adlandırılan düzenin içerisinde yaratıcı tarafından belirlenmiş bir yerinin olduğuna inanılan döngüsel bir sistem olarak algılanmıştır $^{18}$. Bu açıdan Mısır toplumu için düalizm birliği, dengeyi ve iki zıt gücün uyumunu temsil eder. Yukarıda da bahsedildiği gibi Mezopotamya'da ise düalizm tanrıların doğasına, onlara tapınılma ve onlardan korkulma nedenlerine bağlı net ayrımları içerir. Mezopotamya toplumlarının inandıkları tanrılar, insanlara hem yardımcı olurlar ve iyidirler aynı zamanda da kıskanç, kaprisli ve çoğu zaman da yıkıcıdırlar.

Mısır'daki düalizm algısı bağlamında göz kavramı incelendiğinde, bu sembolün Mezopotamya'dan farklı bir biçimde olsa da toplumun her alanına nüfuz etmiş olduğu görülmektedir. Mısırlılar, hayat tarzları ve dünya görüşleri açısından düalizmin daha çok olumlu yönüne odaklanmışlardır. Bundan dolayı da 'gözün' çoğunlukla koruyucu ve ilahi olan iyi tarafını ele almışlardır. Mısır'a ait yazılı metinlerde ve ikonografilerde ilahi göz simgesi olarak şahin tanrı Horus'un iyileşen gözünü temsil eden 'wedjat (wd3-t)'/udjat ${ }^{19}$ ya da Ra’nın kızı Göz Tanrıçasının simgeleri kullanılmıştır.

\section{Levant/Kenan}

Tek tanrılı bir dinin düalizm doktrinini açıklamak ve algılamak çok tanrılı dinlerinki ile kıyaslandığında günümüzün kutsal değerlerinin derinliği açısından çok daha zordur. Levant toplumunda göz sembolizmindeki çift yönlülüğü değerlendirmek için temel alınan kaynak, bu halkın tek tanrılı inancının kutsal kitabı olan Eski Ahit’tir.

16 Manfred Lurker, The Gods and Symbols of Ancient Egypt, Thames and Hudson, London 1980, s. 109.

17 Henri Frankfort, Ancient Egyptian Religion, Columbia University Press, New York 1948, s. 50.

18 Frankfort, Ancient Egyptian Religion, s. 54.

19 Rivka Ulmer, "The Divine Eye in Ancient Egypt and in the Midrashic Interpretation of Formative Judaism", Journal of Religion \& Society, vol. 5, 2003, s. 3; J. H. Elliott, Beware the Evil Eye the Evil Eye in the Bible and the Ancient World, Vol 1: Introduction, Mesopotamia and Egypt, Wipf and Stock Publishers, Oregon 2015, s. 124; Pinch, Misir Mitolojisi, s. 200. 
Eski Ahit’te iyi ve kötü arasındaki düalizmden bahsederken iyilik açısından tek, kötülük açısından ise iki boyutlu bir kötülüğe değinmek gerekir. Bunlar, tek bir Tanrı'nın iyiliği, yüceliği ve sunduğu yaşam ile kendi yaratmış olduğu kötülük yani 'şeytan'a ve insanoğlunun yaradılışında var olan içsel kötülüğe dayanmaktadır ${ }^{20}$. Aslında bu iki olgu neden-sonuç ilişkisi içerisinde birbirleri ile bağlantılıdırlar. Eski Ahit’te kötülüğün temsili olan şeytan hakkındaki bilgi sınırlı olmasına rağmen, onun Tanrı'nın kontrolü altında olan ve onun isteğini yerine getiren bir araç konumunda olduğu açıktır. Genel anlamda bakıldığında Eski Ahit’te şeytan, yani kötülük Tanrı'nın insanları sınamak için yarattığı suçlayıcı, iftiracı ve düşman bir aracı varliktır ${ }^{21}$.

İsrailoğullarının kendi toplumlarını yaratmaya başlama tarihi, İbrahim'e dayanırken dinselleşme süreçleri Yahve ile yapılan ahit temeline dayanmaktadır. İbrahim'in Kenan diyarına göç edip vaat edilmiş topraklara yerleşmesiyle de, İbrahim'in tanrısı Yahve'ye/ Yehova'ya olan inanca geçilmiştir. Yahveizmin tarihsel doğası tek ilahtan oluşmaktadır ve çok tanrıcılığı reddetmektedir ${ }^{22}$. Eski Ahit'te bu inancı destekleyen çok fazla referans yer almaktadır ${ }^{23}$. Ancak son zamanlarda yapılan çalışmalar, erken dönem İsrail halkının Kenan baş tanrısı Baal'a da taptıklarını, yaşam biçiminin bu tanrıdan oldukça etkilendiğini ve tek tanrı inancına geçiş sürecinin oldukça uzun bir süre aldığını ortaya çıkarmıştır ${ }^{24}$.

Levant toplumu Yahve'yi, panteonun bir üyesi ya da lideri olarak değil, gökyüzünde ikamet eden ve belirli aralıklarla yeryüzüne inen tek başına var olan bir güç olarak düşünmüşlerdir ${ }^{25}$. Yahveizmin/Yahudiliğin en önemli ve göze çarpan özelliği, Yahve'nin/RAB'bin ${ }^{26}$ olumlu ve olumsuz özelliklerinin bir birleşimi olmasıdır. O, İsrail'in lideri ve koruyucusudur, İsrail'in düşmanlarının tanrılarından üstün ve halkının yaşamlarında aktif olarak yer almıştır. Öte yandan, tutkulu bir yapısı vardır ve kışkırtıldığında şiddete yatkın şeytani bir karaktere de

20 'Şeytan' kavramının detaylı anlatımı ve Eski Ahit'teki referansları için bkz. Harun Işık, "Kitab-ı Mukaddes ve Kur'an'a Göre Şeytan”, Bozok Üniversitesi İlahiyat Fakültesi Dergisi [BOZIFDER], sayı 13 (2018), s. 35-74.

21 Işık, a.g.m., s. 35.

22 Haldun K. Akalın, "Yahve ve Kenan Tanrıları", Sosyal Bilimler Dergisi, XIV/1 (2012), s. 100.

23 Çıkış 20: 2, Tesniye 5: 6, Hoşea 11: 1-2, 7, Yeşaya 45:5, Tesniye 32:39 vb.

24 Liezl Durie, Dualism in Jewish Apocalyptic and Persian Religion, Yayınlanmamış Yüksek Lisans Tezi, Stellenbosch University, 2012, s. 13.

25 George Fohrer, History of Israelite Religion, S.P.C.K, London 1973, s. 77.

26 Yahudilik, semitik ve ilahi kökenli olarak kabul edilen dinlerin en eski olanıdır. Bu dinlerin ortak noktası tek tanrı inancını kapsamalarıdır. Bu tanrıya hitap ederken kullanılan isimlerin her biri farklı bir kelime ile ifade edilmiştir. Bu İsimler, Yahudiler için YHVH, Hristiyanlar için Baba-Tanrı ve Müslümanlar için ise Allah'tır. Bunlardan Hristiyanların Yehova olarak seslendirdikleri ancak Yahudiler' in seslendirmeksizin YHVH/YHWH şeklinde muhafaza ettikleri isim ise pek çok tartı̧maya sebep olmuştur. Yahudiler bu ismi yüzyıllardır telaffuz etmemektedirler. Fuat Aydın, "Bir Sessizliğin ya da Yhvh'nin Tarihi (YHVH'nin Telaffuz Edilmeme Olgusu Uzerine Bir Araştırma)”, Usul, sayı 2 (2004), s. 104. Bu inanca göre Tanrı'nın özel ismini dillendirmek yasaktı ve bu nedenle Tanrı'nın isminin geçtiği bir cümle okunurken bu isim yerine "RAB" ya da "Tanrı" ifadeleri kullanılmıştır. 
sahiptir ${ }^{27}$. Eski Ahit, Yahve'yi hem 1şı̆̆ı hem de karanlığın kaynağı olarak tasvir eder ${ }^{28}$. Yukarıda bahsedilen diğer iki antik dindeki kötü varlıklara atfedilen her türlü gizemli ya da korkunç bir olay RAB’BIN kendisine atfedilir. Dolayısıyla, İsrail toplumunun gözünde 'kötülük' kavramının tutarlı bir resmini oluşturmak zordur ve bağımsız bir kötülük temsilcisi bilinmemektedir ${ }^{29}$. Yahve'nin doğrudan bizzat kendisinin ya da melekler aracilığıla yeryüzünde olan kötülüklerden sorumlu olduğu ve kötülüklere izin verdiği Eski Ahit’in bazı bölümlerinde ima edilmiştir ${ }^{30}$.

Kötülüğün, tek ilah RAB'da dolaylı ya da doğrudan var olma düşüncesinde, hem her şeyi bilme yetisine, saf iyiliğe hem de kutsallığa tezat düşen noktalar vardır. Bu inançta iyi ve kötü Tanrı ile başlatılmıştır; ancak aynı zamanda insanoğlunun kendi özgür iradesi ile de üretilir ve yaşatılır. İyi ve kötü düalizmi bağlamında İsrail halkının inancında varlığına inandıkları kötülüğü tercih etmeme seçenekleri vardır. Bu durum Eski Ahit’te oldukça açık bir şekilde dile getirilmiştir: "Senin önüne hayatla ölümü, bereketle laneti koyduğuma, gökleri ve yeri size karşı bugün şahit tutuyorum; bunun için hayatı seç". ${ }^{31}$ Bu bağlamda kötülük daha çok insanlığın ahlaki seçimleriyle ve kararlarıyla özdeşleştirilmiştir. Bireye bahşedilen özgür irade kötülügün simgeleri haline gelen hırs, fesatlık, nefret, kıskançlık ve sinir gibi düşünsel ve duygusal özellikleri kalbinde toplayıp gözünden yansıtabilir ve böylece kötülük dünyada var olmuş ve yayılmış olur ${ }^{32}$.

İnsanın ahlaki ve etik değerleri ilahi taleple çakıştığında kişi gerçekliğin farkındalığına ulaşmaya zorlanır. Eski Ahit’te olan bu yeni farkındalık, İsrail dini ile Eski Mezopotamya ve Mısır inançlarında yer alan göz kavramındaki ve iyi/kötü düalizmindeki farklılıkları gösterir. Mezopotamya ve Mısır'da ilahi hayata dair pek çok ikonografi bulunmaktadır. Ancak İsrail dini ile ilgili neredeyse hiç görsel betimleme yoktur ve dini açıklamalar tamamen yazılı ve sözlü gelenekle devam etmiştir. Bu bağlamda, Mezopotamya ve Mısır'da yer alan göz sembolizmi hem yazılı hem de görsel olarak İsrail'dekinden çok daha geniş kapsamlıdır. İsrail dininde göz, daha çok metaforik olarak yazılı dilde kendini göstermiştir. Antik

27 Fohrer, a.g.e., s. 78.

28 "Işı̆̆a şekil veren ve karanlı̆̆ yaratan; barışıklık eden ve bela yaratan; bütün bunları yapan RAB benim". İşaya 45:7.

29 Durie, a.g.e., s. 16.

30 "Ve RABBIN Ruhu Sauldan ayrlld, ve RAB tarafindan kötü bir ruh onu üzüyordu. Ve Saulun kulları kendisine dediler: İşte şimdi, Tanrı tarafindan kötü bir ruh seni üzüyor.” 1. Samuel 16: 14-15. "Ve Mikaya dedi: Öyle ise RABBIN sözünü dinle: RABBİ tahtı üzerinde oturmakta, ve bütün gökler ordusunu onun yanında, sağında ve solunda durmakta gördüm. Ve RAB dedi: Ramot-gileada çıssın da düşsün diye Ahabı kim kandıracak? Kimi şöyle kimi böyle dedi. Ve bir ruh çıkıp RABBIN önünde durdu, ve dedi: Ben onu kandırırım. Ve RAB ONA DEDI: Ne ile? Ve dedi: Ben çıkarım, ve bütün peygamberlerinin ağzında yalancı bir ruh olurum. Ve dedi: kandırırsın, hem de onunla başa çıkarsın; çık ve öyle yap. Ve şimdi, işte RAB senin bütün bu peygamberlerinin ağzına yalancı bir ruh koymuştur; ve RAB senin hakkında şer söylemiştir." 1. Krallar 22: 19-23.

31 Tesniye 30:19.

32 Helen L. Seawright, The Symbolism of the Eye in Mesopotamia and Israel, Yayınlanmamış Yüksek Lisans Tezi, Laurier University, Ontario 1988, s. 114. 
Mezopotamya'da bu sembolün kötü yönü ön plana çıkarken Mısır ve İsrail'de gözün ilahi, koruyucu ve her şeyi gören anlamları dikkat çekmiştir.

Bir canlının yaşadığı hüzün, acı, öfke ve yoğun duygu anlarında gözden akan yaşlar, sağlıklı ve mutlu ya da hasta olma durumlarının gözden anlaşılması ve ölüm anında kapanması gibi refleksler, antikçağlardan bu yana insanları gözü sadece organ olarak düşünmekten çok daha farklı boyutlara taşımış ve doğaüstü anlamlar yükleme eğilimine itmiştir. Göz, dünyevi ya da doğaüstü bir varlığın tüm iyi ve kötü duygularını, düşüncelerini ve davranışlarını yansıttığ bir araç olmuştur. Yüzün en canlı ve çarpıcı bölgesi olarak göz, bir yaşam indeksi ve yaşam kuvvetinin varlığı gibi ruhun dişarıya açılan penceresidir.

\section{B. Eski Yakındoğu'da Göz Sembolizmine Düalist Yaklaşım 1. Kem Göz İnancı}

Kem göz inancının mantıksal çözümlemesinde, kötü düşüncenin ve saldırganlık hissinin yoğun dik bakış ya da kıskançlık içeren fesat bakış ile çevreye yansıtılması yer alır. Göz, negatif yoğun duyguları içeren bu enerjiyi, insanlara, tüm canlı varlıklara ve cansız nesnelere yönelterek yaralanmalara, hastalıklara, kayıplara, çürümelere, doğal afetlere ve bazı inanışlarda ölüme bile sebep olabilir ${ }^{33}$.

$\mathrm{Bu}$ inancın yaygın coğrafi dağılımı ve binlerce yıldan beri devam eden uzun tarihi, bu kavramı basit ifadelerle tanımlamayı imkânsız kılmaktadır. Kem göz kavramının ilk ortaya çıkışı, yayılım alanı, toplumlarda yarattığı alg1 ve hayatı etkileme biçimi, pek çok araştırmacının ilgisini çeken bir konu olmuştur ${ }^{34}$. Elliott, coğrafi olarak kem göz inancının kökeninin Mezopotamya medeniyetinin en eski toplumu olduğu düşünülen Sümerlere dayandığı ve bu bölgeden Mısır'a ve Akdeniz medeniyetlerine dağıldığını belirtmiştir ${ }^{35}$.

Bazı araştırmacılar bu olgunun kaynağını ekonomik nedenlere dayandırmışlardır. Gershman, kem göz inancının yıkıcı kıskançlığın gerçek bir tehdit olduğu, yani servet eşitsizliğinin üst seviyelerde ve mülkiyet haklarını uygulayan resmi kurumların eksik olduğu dönemlerde başladığını ileri sürmüştür. Dahası Gershman, mekânsal ve kültürler arası yayılma, sosyo-ekonomik karmaşıklık ve büyük dünya dinlerine maruz kalma gibi değişkenler hesaba alındığında, kötü göz inancının, sosyo-ekonomik eşitsizlik yaşayan toplumlarda daha yüksek oranda olduğunu açıklamıştır ${ }^{36}$.

33 John H. Elliott, The Evil Eye with modifications in The Ancient Mediterranean Social World: A Sourcebook, ed. Zeba Crook, Eerdmans Publishing Company, Grand Rapids 2016, s. 2.

34 Son zamanlarda, 'kem göz' inancını en kapsamlı ve detaylı inceleyen bilim insanı John H. Elliott'tur. Bu içeriğin Eski Mezopotamya dininden başlayarak Hristiyanlığa dayanan serüvenini Beware the Evil Eye the Evil Eye in the Bible and the Ancient World başlı̆̆ altında dört ciltlik eserinde açıklamıştır.

35 John H. Elliott, Beware the Evil: Eye the Evil Eye in the Bible and the Ancient World, Vol 1: Introduction, Mesopotamia and Egypt, Wipf and Stock Publishers, Oregon 2015, s. 77.

36 Boris Gershman, "The economic origins of the evil eye belief", Journal of Economic Behaviour and Organization, say1 110 (2015), s. 137, https://doi.org/10.1016/j.jebo 12.002. 
Bu tür ekonomik sebeplere dayalı bir yaklaşımın yanı sıra kem gözün, özellikle ortaya çıktığı düşünülen bölge ve dönemin inanç sisteminin getirdiği koşullar ve sebep sonuç ilişkisinin noksanlığı ile yani genel anlamda sosyo-kültürel durum ve evren algısı ile de doğrudan bağlantılı olduğu düşünülmektedir. Kültürel olarak Eski Mezopotamya ve Eski Mısır toplumları evrenin, yüce tanrılar ve ilahi varlıklar, şeytanlar, ruhlar, iyi ve kötü niyetli doğaüstü güçler, hayaletler, insanlar, cadılar, büyücüler, din adamları, rahibeler, kâhinler, fahişeler ve rüya yorumcuları tarafından ikamet edildiğine ve yönetildiğine inanmışlardır.

Özellikle kem gözün ortaya çıktığı Mezopotamya toplumları yaşadıkları dünya ile ilgili kararları, uyguladıkları ritüellerin getirdiği sonuçlar doğrultusunda alırlar ve başlarına gelen hastalık, talihsizlik, kıtlık ve afet gibi her türlü felaketin sebebinin öfkeli veya kaprisli tanrılar, demonlar, kötü ruhlar ve kem gözlü düşman insanlar olduğuna inanırlardı. Zararlara karşı ritüeller, dualar, büyülü sözler, tılsımlar, muskalar ve çok çeşitli kötülük kovucu önlemler alınırdı. İyileştirme umudu kötülük kovucu ritüellere, güçlü kelimelere, isimlere, mimiklere ve tesirli sözcüklere bağlanırdı. Bu tür toplumlarda kutsama ve lanetleme ikileminin etkinliğine, doğaüstü varlıklar ile iletişimin gücüne, doğa olaylarından yararlanılarak elde edilen kehanetlere, göksel âlemlere, genel olarak doğanın kuvvetlerini etkileme ve kullanma gücüne güven duyulurdu ${ }^{37}$. Doğaüstü normların bu derece güçlü olduğu toplumlarda kem gözün oldukça etkin bir şekilde felaket getirebileceği olasılığı akla yatkındır. Özellikle çocukların, hayvan sürülerinin ve geçinmek için kullanılan tarım araçları gibi yaşamda değerli olan her şeyin kem göze ve kıskanç bakışa karşı savunmasız ve bu nedenle de gizlenme ve korunmaya muhtaç olduğu düşülmekteydi.

\section{a. Mezopotamya}

Mezopotamya'da III. binyılın sonundan Yeni Babil Dönemi'ne kadar pek çok kayıtta "kem göz" olgusunun izine rastlanmıştır. Kem göz ile ilgili yazılı kanıtlar, Sumerce ve Akadca dillerinde mevcuttur. Kötülük kovma metinleri, çoğunlukla Akadca olarak bulunmuşken kem göze karşı ritüel ve dua metinlerinin dikkat çekici kısmının Sumerce olduğu anlaşılmaktadır ${ }^{38}$. Yakındoğu'da kem göz algısını araştıran Thomsen, Wasserman ve Ford, ilk olarak Mezopotamya'da kem gözün, kıskanç ya da fesat bir kişinin gözü olarak düşünülmediğini kem göz etkisinin kötülüklerin yegâne sebebi olan demonlardan kaynaklandığını ileri sürmüşlerdir ${ }^{39}$. Bu demonlardan bebek hırsızı ve anne katili olarak bilinen Lamaštu kem göz ile en çok bağdaştırılan kötü güçtür ${ }^{40}$.

37 John H. Elliott, Beware the Evil Eye the Evil Eye in the Bible and the Ancient World, Vol 3: The Bible and Related Sources, Wipf and Stock Publishers, Oregon 2016, s. 3.

38 Louise Thomsen, "The Evil Eye in Mesopotamia", Journal of Near Eastern Studies, LI/1, The University of Chicago Press, 1992, s. 28.

39 Nathan Wasserman, "Seeing Eye to Eye: Concerning Two Incantations Against Lamashtu's Evil Eye", Nouvelles Assyriologiques Bréves et Utilitaires, 1995, s. 6; James N. Ford, "Ninety-Nine by the Evil eye and One from Natural Causes", KTU2 1.96 in its Near Eastern Context, Ugarit- Forschungen, say1 30, 1998, s. 209.

40 Lamaštu demonunun yarattığı kötü etkiler için bkz. Dilek, a.g.e., s. 88. 
Bazı metinlerde demonların gezinen kem gözlerinden bahsedilmektedir. Bu gözlerin hipnotize etkisi yarattığına ve demonun kişiyi gözleriyle bilinçsiz hale getirerek içerisine girebildiğine inanılmıştır. Bir kişi, gezici demon gözü tarafından hipnotize edilirse demonun kendisi gibi davranırdı. Bu durum, demona daha çok güç kazandırırdı ve kişi, bilinçsizce ortalıkta dolanır, içerisindeki kötü güç nedeniyle bitip tükenir ve hatta içindeki demon tarafindan katledilebilirdi ${ }^{41}$. Ancak bu, çok nadir görülen bir durumdur ve kem göz Mezopotamya'da ölümden daha küçük çaplı felaketlere sebep olduğu düşünülen bir kavram olarak ortaya çıkmıştır. Bu toplumda demon bağlantılı kem gözün kişiyi tüm diğer uğursuzluk ve kötülük getiren güçler kadar çok etkilediğine inanılmıştır.

Mezopotamya'da kem göz, daha çok demonlarla ve kötü ruhlarla ilişkilendirilse de bu inanç, aynı zamanda kara büyüyle ve insanların sebep oldukları kötülüklerle de bağlantılıdır. Ancak kara büyünün yarattığı etki ile kem gözün yarattığı etki de tamamen aynı olarak algılanmamıştır ${ }^{42}$. Bir kişinin sadece gözlerinin gücüyle başka bir kişiye, hayvana ya da nesneye zarar verebilmesi, bazı günümüz toplumlarında da inanılan bir durumdur. Mezopotamyalılar kem gözü, yukarıda da bahsedildiği gibi insandan çok demonlara bağlamışlar ve ölüme sebep olacak kadar etkili olmayan ancak sıkıntı ve dert gibi kötü etki yaratan bir güç olarak düşünmüşlerdir. Onların düşüncelerine göre kem göz, herkesin her zaman başına gelebilecek kazalara, az yağmur yağmasına, peynir yapımının yanlış gitmesine, bir eşyanın kırılmasına, kıyafetlerin yırtılmasına vb. olaylara sebep olmaktadır.

Kem gözün etkili olduğu durumlar, Sumerce ve Akadca ritüel metinlerinde oldukça net bir şekilde açıklanmıştır. Sumerce kem göze karşı hazırlanan bir ritüel metninde sebep olduğu etkiler şu şekilde açıklanmıştır: “Kem göz gökyüzüne yaklaştı- yă̆mur yağmadl, topră̆a yaklaştı- otlar büyümedi, öküze yaklaştı-bă̆ı açıldl, sı̆̆ıra yaklaştı- peynir bozuldu, koyun ahırına yaklaştı ve koç çalındı. Genç bir adama yaklaştı-adamın kemeri yırtıldı-(gücü bağlandı), genç bir kadına yaklaştı- kıyafeti düştü. "’43

Akadca bir metinde de kem gözün benzer etkileri anlatılmıştır: "Sen kem göz! Çömlek fırınını bozdun, denizcilerin teknesini batırdın, güçlü öküzün boyunduruğunu bozdun, koşan eşeğin bacaklarını kırdın, becerikli dokumacı kadının dokuma tezgâhını bozdun, koşan atın tayını düsürttün ve boğanın yoldaşını düşürttün, yanan tütsüyü dă̆ıttın, Adad'ın liderliğinde, vahşi hayvanları aşă̆ı attırttın, kardeşler arasına tartışma soktun. ",44

41 Susan Limmer, The Social Functions and Ritual Significance of Jewelry in the Iron age II Southern Levant, Yayınlanmamış Doktora Tezi, The University of Arizona, Arizona 2007, s. 38.

42 Thomsen, a.g.m., s. 22.

43 Thomsen, a.g.m., s. 23.

44 VAT 10018: 8-15. Bu iki metne ek olarak iki dilli bir diğer metinde de kem gözün sebep olduğu sıkıntılar şu şekilde açıklanmıştır: "Kötülüğün gözü, huzursuz adam, köşeye bakarsa, köşeyi boşaltır, evin bir kenarına bakarsa, o kenarı boşaltır. Ülkenin yaşanan topraklarına bakarsa, orayı boşaltır. Huzursuz bir adama bakarsa, adamın boynunu bağlar ve ağaç kırılmış ăgaç gibi keser.” CT 16: 5-9. Thomsen, a.g.m., s. 24. 
Mezopotamya'da kem göz kavramına dair yaptı̆̆ı araştırmalarda Thomsen, bundan korunma yöntemleri geliştiren Mezopotamyalıların uygulamalarında en çok, çeşitli taşları ve göz şekli verilmiş objeleri kullandıklarından bahsetmiştir. Bu uygulamaya dair bir yönlendirme şu şekildedir: "Bira libasyonu uygula ve şunları söyle: "Ben tanrıma ya da tanrıçama ne yaptım? Dualarımı dikkate al ve ben kudretini beyan edebileyim.” Bunu üç kere söyle ve yanan tütsüyü nehre at. Kem göz adama yaklaşamasın." ${ }^{45}$ Mezopotamya'da kem göz kavramı demonlarla direkt ilişkili olduğu için uğursuzluk ve kötülük getirirlerdi ve bundan korunmak için ritüel uygulamalarından çok tılsımlar, muskalar, taşlar ve çeşitli göz tasvirlerini barındıran objeler gibi koruyucu nesnelerin kullanımı yaygındı.

Göz imgesinin Mezopotamya'da her zaman güçlü bir tılsım olduğuna inanılırdı. Göz imgelerinin kullanıldığı objelerin yapılış sebebi, bu din algısının içerisinde 'kem göz' kavramının hâkim olmasıdır. Kem gözden korunmak için göz imgeli nesnelerin üretilmiş olması, sempati büyüleri ${ }^{46}$ bağlamında Frazer'ın öne sürdüğü 'benzerlik yasasıyla' bağlantılı bir durumdur ${ }^{47}$.

Kem gözden korunmak için uygulanan en yaygın yöntem, genellikle camdan ya da başka bir materyalden yapılmış göz imitasyonlarının muska olarak boyna asılmasıdır. Mezopotamya'da göze ya da bir çift göze benzeyen boncukların muska olarak kullanılmasına dair kanıtlar, ritüel metinlerde, tapınaklarda bulunan boncukların arasında ve ikonografilerde yer almaktadır ${ }^{48}$. Ancak, Mezopotamya'da kem gözden kurtulmak için sadece göz imgeleri kullanılmamıştır. Thomsen'ın belirttiğine göre, kem göze maruz kalmış kişinin başına, bükülmüş ve düğüm atılmış yünlerin bağlanması gibi yöntemler de bazı durumlarda kem gözün etkilerini yok edebilirdi"49. Yünün kem gözden kurtarıcı olduğu bir ritüel metni şu şekildedir: "Tek öküzgözü, tek koyungözü, birçok adamın gözü, birçok adamın ă̆zl, göz kötü, en kötüsü. Asarluhi bunu gördü, tapınakta babası Enki’yi görmeye gitti ve şunları söyledi: “Baba, göz, tek öküzgözü, göz tek koyungözü! Ne yapabilirim bilmiyorum, onu ne tedavi edebilir? Enki Asarluhi'ye cevap verir: "Evladım, senin bilmediğin ne? Ne ekleyebilirim? Ben ne biliyorsam, sen de biliyorsun. Git oğlum, siyah ve beyaz yünü başına bağla. ” Adamı kötü yapan kem göz öküzün boğazının kesildiği gibi kesilir!',50

45 Thomsen, a.g.m., s. 27.

46 Elworthy, sempati büyülerinin temel yasasının kişinin deneyimleri sonucunda ortaya çıkan düşüncelerini gerçeklerle ilişkilendirmek için benzer bağlantılar kurması sonucunda ortaya çıktığını ileri sürmüştür. Sempatik büyünün temel prensiplerinden biri, herhangi kötü bir etkiyi yok etmek için onun imitasyonunun kullanılmasıdır. Frederick Thomas Elworthy, The Evil Eye an Account of This Ancient Widespread Supersitition, Murray, London 1895, s. 48.

47 Frazer, 'benzerlik yasasını' ileri sürerek 'benzer benzeri çeker' olgusuyla nesnelerin sempati büyülerindeki diğer varlıklarla olan ilişkisini açıklamıştır. 'Benzer' benzerin üzerinde hâkimiyet kurabilmiş ve 'benzer' bir durumu tedavi etmek, düzeltmek ve iyileştirmek için kullanılabilmiştir. Örneğin; ödem tedavisi için suyun bol içilmesi gerektiği gibi. Bunun tam tersi olan 'zıtlıklar kanunu' da aynı doğrultuda ancak farklı işleyişle ortaya konulmuştur. James G. Frazer, The Golden Bough: A Study of Magic and Religion, vol. 1, Second Edition, Macmillan and Co., Ltd, London 1900, s. 9.

48 Thomsen, a.g.m., s. 22; Limmer, a.g.t., s. 39.

49 Thomsen, a.g.m., s. 26.

50 YOS 11: 1-18. Thomsen, a.g.m., s. 29-30. 
Thomsen'ın belirttiğine göre, kem gözü yok etmek için talimatların net bir şekilde verildiği diğer bir ritüel metin şu şekildedir: "Bira serp ve şunları söyle: "Ben tanrıma ya da tanrıçama ne yaptım? Dualarımı dikkate al ve senin yüceliğini beyan edeyim” bunu üç kere tekrar et ve sonra tütsü kabını nehre at. Kem göz adama yaklaşamaz." ${ }_{51}$

Evans'a göre, göz simgeli her nesne koruyucu bir güçle bağlantıliydı ve kem göze karşı alınan bir önlemdi. Orta Asur Dönemi’ne ait bir kolyenin de bu amaçla yapıldı̆̆ düşünülmektedir. Bu kolyenin ortasında granülden yapılmış üç adet altın tabanlı, kedigözü oniks taşı bulunmaktadır. Kenarları da farklı şekillerde ve farklı boyutlarda, lapis lazuli, kantaşı, akik, kuartz ve oniksten yapılmış boncuklarla süslenmiştir ${ }^{52}$.

Bazıları kırık, bazıları ise sağlam olarak, çoğunluğu beyaz ve siyah su mermerinden yapılmış, yirmi bine yakın göz sembolü, muska ve boncuklarla birlikte Tell Brak'da keşfedilen Göz Tapınağı'nda bulunmuştur. Bu semboller yaygın olarak iki daireyi içeren, çoğunlukla delinmemiş ve eğik bir çerçeveyle birleştirilmiş şekildedirler ${ }^{53}$.

Mezopotamya'da heykellerin gözleri de oldukça dikkat çekicidir. Gözler genellikle lapis lazuli taşından yapılmıştır ve bu taşın sahip olduğu ilahi sembol ${ }^{54}$, bunların koruyucu amaçlı koyulduğunu düşündürtmektedir. Özellikle tapınaklarda bulunan bu heykellerin gözleri oldukça ön plana çıkarılmış ve sistemli bir şekilde düzenlenmiştir. Tapınaklarda bulunan gözlerin amacına dair tartışmalar devam etmektedir. Kimi uzmanlar, bu simgelerin bir tanrıya adandığını iddia etmekteyken bazıları diğer muska ve boncuklarla aynı işlevde yani koruyucu amaçlı olduklarını savunmaktadırlar ${ }^{55}$. Tapınaktaki amaçları tartışmalı olmasına rağmen ritüel metinlerinden de anlaşılacağı gibi kişisel olarak kem göze maruz kalma durumunda ya da kem gözden korunmak için çeşitli materyallerden yapılmış göz simgeli nesneler, Erken Hanedanlık Dönemi’nden Yeni-Asur Dönemi’ne kadar, Mezopotamya sanatında yaygın olarak kullanılan bir motif olmuştur ${ }^{56}$.

51 BAM 374: 3-8. Thomsen, a.g.m., s. 27.

52 M. Jean Evans, "The Middle Assyrian Period", Beyond Babylon: Art, Trade and Diplomacy in the Second Millenium B.C., ed. Joan Aruz, Kim Benzel, Jean M. Evans, The Metropolitan Museum of Art, New York Yale Univerity Press, New Haven and London 2008, s. 213.

53 Laura Goff, Symbols of Prehistoric Mesopotamia, Yale University Press, New Haven and London 1963, s. 149150 .

54 Lapis lazuli taşının tanrısal simgesi ve ilahi atıfları onu, Mezopotamya dininde ve ritüellerinde çok özel bir yere koymaktadır. Bu taş, kutsallığını öncelikle kozmolojik anlamına borçluydu ve yıldızlı geceyi dolayısıyla da göğe ışık getiren parlaklığıyla, ay tanrısı NANNA/Sin ’i temsil ederdi. Kabartmalarda ay tanrısı, yıldızlı gecenin tanrısı Sin 'in sakalı, bu taştan yapılmıştır. Bu mavi taş, bütün yıldızlı göğün büyüsünü ve aya bağlı olan tüm erdemleri nitelemiştir. Samuel Noah Kramer, Sumer Mitolojisi, çev. Hamide Koyukan, Kabalcı Yayınevi, İstanbul 2001, s. 86; Mircea Eliade, Dinler Tarihine Giriş, çev. Lale Arslan Özcan, Kabalcı Yayınevi, İstanbul 2014, s. 419; ayn.yzr., Babil Simyası ve Kozmolojisi, çev. Mehmet Emin Özcan, Kabalcı Yayınevi, İstanbul 2002, s. 43.

55 Goff, a.g.e., s. 152; Jeremy Black- Anthony Green, Mezopotamya Mitolojisi Sözlüğ̈̈. Tanrllar Iritler Semboller, Köprü Kitapları, İstanbul 2017, s. 123.

56 Black- Green, a.g.e, s. 123. 


\section{b. Misır}

Mısır medeniyetinin evren algısı ve inanç sistemi yukarıda da bahsedildiği gibi Mezopotamya toplumlarınınkinden farklıdır ve daha çok olumlu açılara yönelmiştir. Mısır'da sonunda hedeflenen iyi bir amaca ulaşmak uğruna ve dengeli bir yaşamı sürdürmek için iyinin ve kötünün bütünlük, denge ve uyum sergilediğine inanılmıştır. Bu bağlamda, Mısır toplumu göz kavramında var olduğuna inanılan yıkıcı ve koruyucu özelliklerden koruyucu olanına daha çok odaklanmıştır. Ancak bu algı, Mısır'da kem göz inancının tamamen yok olduğunu göstermez ve Mezopotamya'dakinden farklı da olsa antik Misır medeniyetinin de kendi hayat algısı doğrultusunda bir 'kem göz' inancı olduğu söylenebilir. Bu inancın varlığı, yazılı metinlerde ve ikonografilerde yer alan tanımlar ve ona karşı alınan koruma yöntemleriyle de kanıtlanmıştır.

Mısır'ın göz imgesine olan ilgisi sanatta, edebi eserlerde ve hatta kişisel takılarda çok belirgin bir şekilde görülmektedir. Göz sembolüne duyulan ilginin içerisinde iyi ve kötü düalizmi doğrultusunda kem gözle de bağlantılı bir boyutunun olduğu var sayılmaktadır. Mısır'a ait sanat eserlerinde göz ve gözler özellikle vurgulanmış ve çarpıcı renklerle ön plana çıkarılmıştır. Çeşitli boyutlarda göz imgeleri lahitlerde, kapı süslerinde, dikili taşlarda, mezar duvarlarında, teknelerde, papirüs ve muskalarda yaygın bir şekilde yer almaktadır.

Elworthy'nin belirttiğine göre Mısır'ın binlerce yıl önceye dayanan uzun tarihi boyunca pek çok siyasi ve kültürel dalgalanmalar yaşanmıştır. Bu dalgalanmalar yaşamlarında belirli açılardan etkili olsa da bazı kültürel ve dini unsurlar, değişmeden kalmıştır. Bunlardan biri de kem gözün hem sağlara hem de öldükten sonraki ruha dehşet yaşatma potansiyelinin varlığıdı5 ${ }^{57}$. Yukarıda da bahsedildiği gibi, kem göz inancının kökeninin Mezopotamya olduğu düşünülmektedir. Mezopotamya kökenli bu inancın, Mezopotamya ile Mısır arasında gelişen uzun soluklu ekonomik, sosyal ve kültürel bağlantılar sayesinde Misır'da nispeten erken bir tarihte, belki de Orta Krallık'a kadar (MÖ. 2133-1786) ortaya çıkmasını mümkün k1lmaktadir ${ }^{58}$.

Mısır kaynaklarında kem gözden açıkça bahseden metinlerin azlığı ve önceki kaynakların genellikle sonradan yazılı hale geçirilmiş olmasından dolayı, bu bölgede bu kavrama tam olarak ilk ne zaman inanıldığını söylemek oldukça güçtür. Kem gözden aleni bir şekilde bahseden kaynaklar yaklaşık MÖ. 663 tarihlerine dayanmaktadır. Ancak Elliott'un belirttiği gibi, Horus mitleri ve wedjat gözün muska olarak kullanılmasının kanıtları, bu inancın temelinin çok daha öncelere dayandığını göstermektedir ${ }^{59}$. Ölüler Kitabı ve Piramit Metinlerinde Horus mitinin yer alması ve 4. Hanedanlık döneminde (yaklaşık MÖ. 2600)

57 Elworthy, a.g.e., s. 6.

58 Elliott, a.g.e., vol. I, s. 119.

59 Elliott, a.g.e., vol. I, s. 119. 
Horus’un gözünün koruyucu olarak ölü bedenler ile birlikte gömülmesi bölgede bu inancın başlangıcının oldukça eskilere dayandığının kanıtıdır.

Mısırlılar da Mezopotamyalılar gibi kem gözün sağlığa, aile birliğine ve özellikle çocuklara zarar verebilen bir tehdit olduğunu düşünüp aynı şekilde bu kötü güçten kurtulmak için dualar, büyüler ve muskalar kullanmışlardır. Ancak bu toplum farklı olarak kem gözün yıkıcı gücünün demonlardaki kadar insanlarda da olduğuna inanmışlardır. Pinch, Mısır'da cadılarla ilgili verilerin oldukça eksik olduğunu ve bu tür kötü niyetlere en yakın kem göz kavramına sahip insanların varlığını belirtmiş ve kem gözlü insanların kıskanç ve hain mizaçlı olarak düşünüldüklerini ileri sürmüştür ${ }^{60}$. Bu nedenle kem göz ile insanlar arasında kurulan bağlantı 'kıskançlık ve fesatlık' gibi kötü insani duygularla özdeşleştirilmiştir.

Eski Mısır'a ait yazılı eserlerde kem göz kavramı MÖ. birinci binyılın ortalarında ortaya çıkmıştır. Buna rağmen yaygın bir sembolizm olarak Horus'un gözünün her yerde bulunması ve muska olarak kötülüğe karşı kullanılması, kem göz inancının çok daha öncelere dayandığının kanıtıdır. Budge, 'iri-t ban-t... ’ifadesinin kem göz anlamına geldiğini savunarak Edfû tapınağının bir odasındaki duvar yazısının bu varlığı yok etmek için yazılmış olduğunu ileri sürmüştür. Dahası 'sihu' kelimesinin kem gözün büyüleyiciliği ve etkisi anlamına geldiğini iddia etmiştir ${ }^{61}$. 6. Hanedanlık dönemine (MÖ. 2350-2180) tekabül eden antik Mısır bilgelik koleksiyonuna ait bir metinde bir erkeğe, karısının tahribat yaratma potansiyeli olan 'asi bakan gözlerine' dair verilen tavsiyeden bahsetmektedir: "hayatın yolunda gidip evini bulduğun ve karını şevkle sevdiğin zaman... onunla mahkemede uğraşma, onu güçten uzak tut, onu dizginle... Onun baklşları gözünü diktiğinde asi bir firtınadır.... Ancak bu sayede sen onu evinde kalmasını sağlayabilirsin. "62

Mezopotamya'da kem gözle ilişkilendirilmiş demon yeni doğmuş bebeklere ve hamile kadınlara zarar veren Lamaštu olduğundan bahsedilmişti. Mısır'da ise bu, bireysel zarar vermek için uğraşmayan, evrenin düzenini bozmaya çalışan, insanlara bulaşan bir demon değil kaos yaratmayı amaçlayan korkunç bir yaratıktır. Bu konuda da Mısır'daki denge ve döngü düalizminden bahsedilebilir. Mısır'da kem gözle bağlantı kurulan yaratık, her gece güneş tanrısına saldıran daha çok yılan sembolüyle betimlenen Apophis/Apopis/Apep'tir (rrk-yılanı) ve bu yaratığın özellikle gözleri çok ürkütücü olarak tasvir edilmiştir ${ }^{63}$.

60 Gewraldine Pinch, Magic in Ancient Egypt, University of Texas Press, Austin 1994, s. 58.

61 Wallis Budge, Amulets and Superstitions, with 22 plates and 300 Text Illustrations, New York 1978, s. 361.

62 Elliott, a.g.e., vol. I, s. 223.

63 "Apophis sürekli olarak ilahi düzeni tehdit eden kaos canavarlarının en etkilisidir. Kimi zaman kocaman bir timsah olarak resmedilir ama genellikle devasa bir yılan kllığındadır. Apophis her gece güneş tanrısının teknesi yeraltı dünyasından geçerken ona saldırır. Yenilgiye uğratılıp öldürülür ama kaç kez ölürse ölsün yeniden canlanır. $O$, yaratıcı tanrının yılan şeklindeki görünümünün olumsuz karşıtıdır." Pinch, Mısır Mitolojisi, s. 172. Detaylı bilgi için bkz. J. F. Borghouts, "The Evil Eye of Apopis", The Journal of Egyptian Archaeology, vol. 59, 1973, s. 114-150. 
Apophis'in kötülük dolu gözünden belirgin olarak bahsedildiği en erken metin "Ölüler Kitabı, 108” de yer almaktadır. Bu metin güneşin teknesinin Bakhu Dă̆g'na yaklaştığında mürettebatın yılanın ölümcül bakışlarına maruz kaldıklarında nasıl etkilendiklerini ve tanrı Seth'in yılanı nasıl hizaya getirdiğini anlatmaktadır ${ }^{64}$. Aynı temayı içeren bir diğer mitolojik hikâye, Sanduka/Tabut Metinlerinde de görülmektedir. "Cennetin dinlendiği Bakhu dağını biliyorum. O bir plato. 300 sırık uzunluğunda ve 120 sırık genişliğinde. Bakhu'nun efendisi Sebek, bu dă̆ın doğusundadır. Onun evi akiktendir ve o dağın tepesinde 30 sırık uzunluğunda ve bir yılan vardır. Onun üç sırık ötesinde de bir bıçak. Ben, bu yılanın adını biliyorum: 'O, dă̆ında olan, içinde alev olan'. Akşam vakti olduğunda, gözlerini Ra 'ya çevirir. Mürettebat kıpırdamadan kalır ve rotadan şaşılır. Seth ulaşabileceği bir yere doğru eğilir. Büyülü sözlerle ona "hey! Senin ulaşabileceğin bir yerde duruyorum! Teknenin rotasının düzeni sona erdi! uzaktan gören sen, sadece kapat gözlerini! Seni tuză̆a düşürdüm...." "65 Bu hikâyeden ve Apophis ile bağlantılı diğer tüm mitlerden anlaşıldığı üzere, Apophis'in bakışlarının gücü karanlık ile ilişkilendirilmiştir ve hipnotize etme gücü vardır ${ }^{66}$.

Mezopotamya'da olduğu gibi Mısır'da da kem gözden korunmak için büyüler, dualar ve muskalardan oluşan birtakım tedbirler alınmıştır. Bunların içerisinde en yaygın olanı, farklı materyallerden yapılmış ya da belirli yerlere resmedilmiş koruyucu simge haline gelen Horus'un gözü wedjat'tır. Tanrılar arasında en başta Horus'un böyle bir işlevi olduğu görülmekle birlikte onun dışında Thoth'un da kem göze karşı koruyucu özelliklerinin olduğu düşünülmektedir. "Ey Thoth sen benden desteğini esirgemezsen ben kem gözden korkmam "67 Ayrıca Said sülalesinin Mısır’1 yönettiği dönemde (MÖ. 663-525) tanrıçaların kem gözden koruyucu niteliklerinin olduğuna inanıldığına dair kanıtlar vardır. "Nut kem gözü yok eder”, "Neith kem gözü yok eder”, “Chons kem gözü yok eder”, "Sekhmet kem gözü yok eder.”68

\section{c. Levant/Kenan}

İsrail halkının dini inancının sistematik bir çerçevede bütünlük sağlaması, yukarıda da bahsedildiği gibi tek tanrı olarak Yahve'nin kabul görmesiyle başlar ve tüm dini gelişmeler öğretilerle birlikte Eski Ahit’te toplanır. Eski Ahit'te gözün simgesel özelliklerini kapsayan olumlu ve olumsuz pek çok referans yer almaktadır. Bu kutsal kitapta göze yüklenen olumlu sembolik özellikler arasında ilk olarak Tanrı'nın gözü olarak her şeyi gören ilahi göz sembolizmi yer almaktadır. Bunun yanı sıra, belirli bölümlerde gözün kavrama yetisi ${ }^{69}$,

64 Borghouts, a.g.m., s. 114.

65 Borghouts, a.g.m., s. 114.

66 Yılanların en yücesi Apophis canavarının kem gözle bağlantılı detaylı betimlemeleri için ve Apophis dışında yılanların bakışlarının yarattığı tehlikeye karşı yazılmış büyülü sözler için bkz. Borghouts, a.g.m.

67 Elliott, a.g.e., vol. I, s. 152.

68 Elliott, a.g.e., vol. I, s. 119.

69 Tekvin 3:4-7., Eyub 42:5., Işaya 6:10. 
alçakgönüllülüğğ ${ }^{70}$, yargılama ve fikir sahibi oluşu ${ }^{71}$, sağlık ve hastalığı yansıtmas $1^{72}$, acıma özelliğ $\mathrm{i}^{73}$ ve iyiliğ $\mathrm{i}^{74}$ ön plana çıkartılmıştır. İsrail halkının inanışının temeli olan bu kutsal kitapta, göz ile ilişkilendirilen olumsuz sembolik özellikler arasında ise en çok kıskançlık, fesatlık, öfke ${ }^{75}$ ve aşağılama ${ }^{76}$ gibi kötü insani hisler vurgulanmıştır. İsrail halkının göz kavramına yüklemiş olduğu bu kadar sembolik unsur içerisinden, düalizm boyutunda bu çalışma kapsamına uygun olanlar, zarar verme gücü olan fesatlığı yansıtan kem göz ile koruyucu ve her şeyi gören ilahi gözdür.

Başarı, zenginlik ya da güzellik gibi başkasının sahip olduğu iyi bir şeye karşı hissedilen kıskançlık ve fesatlık içeren insani duyguların gözde yoğunlaşıp bir canlıya ya da bir nesneye zarar verebilme gücünün olduğuna inanılması, yukarıda da bahsedildiği gibi antik dönemde oldukça yaygın bir durumdu. Elworthy'nin belirttiği gibi herhangi biri etrafında bulunan güzel bir şeye kıskanç gözlerle baktığında bulunduğu çevre, tehlikeli ve kötü özelliklerle dolar ve kendi zehirli ruhunu etrafında ne varsa aktarır ${ }^{77}$. Her ne kadar İsrail halkı gözün sembolik olarak pozitif yönlerine odaklanmış olsa da fesatlık duygusunun gözden yansıyarak zarar verme gücünü yok saymamışlardır. Kıskançlığın göze yansımasının kanıtlarından biri Saul'un Davud'a kem gözle baktığını anlatan bölümdür: "Ve kadınlar oynarken karşılıklı terennüm edip diyorlardl: "Saul vurdu binlerini, Davud da on binlerini. Ve Saul çok öfkelendi, ve bu söz gözünde kötü göründü; ve dedi: Davud'a on binleri verdiler, bana ancak binleri verdiler; ve ona ancak krallık kaldı. Ve o günden sonra Saul Davud'a iğri gözle baktı. "78

İnsanın düşündükleri ve duyguları ile göze yüklenen sembolik bağlantının görüldüğü bir diğer referans ise Süleyman'ın Mesellerinde yer almaktadır: "Zengin olmak için kendini yorma; bu akıldan vazgeç. Olmayan şeye göz diker misin? Çünkü zenginlik mutlaka kanatlanır, kartal gibi göklere uçar. Kötü gözlü adamın ekmeğini yeme, onun çerezlerini de canın çekmesin; çünkü içinden nasıl düşünürse kendisi öyledir; Sana: ye, iç, der; Fakat yüreği seninle beraber değildir. Yemiş olduğun lokmayı kusarsın, ve güzel sözlerin boşa gider. "79 Aynı bölümden bir diğer referans ise şu şekildedir: "Kötü gözlü adam zenginlik ardından koşar; ve üzerine yoksulluk geleceğini bilmez. ",80

Eski Ahit'te RABBIN emirlerine uymayan ve verdiği bolluklara şükretmeyen kişilerin başlarına bazı felaketler geleceğinden bahsedilmektedir ve bunlardan biri de göz

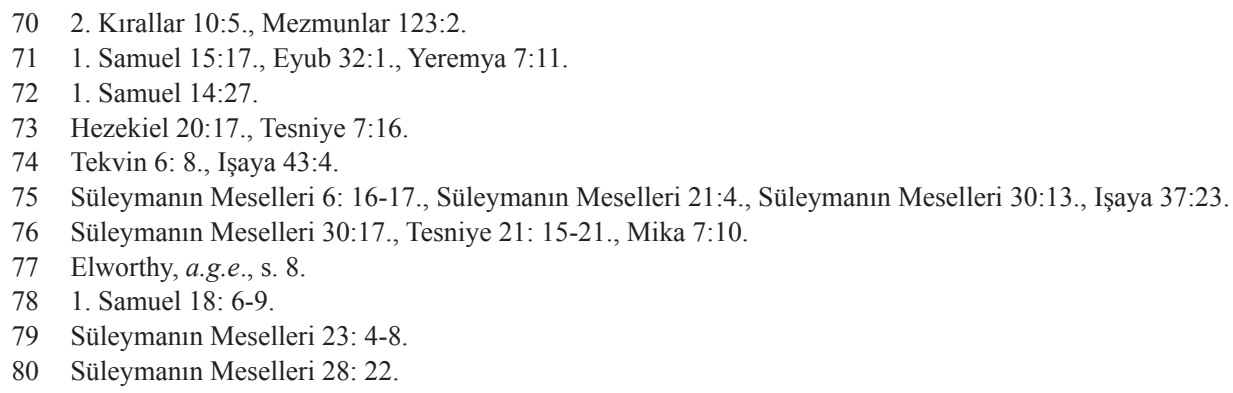


sembolizminin kötü boyutunu ele almaktadır: "Aranızda olan nazik ve çok zarif adamın gözü, kardeşine karşı ve koynundaki karısına karşı ve çocuklarının artakalanlarına karşı kötü olacak. Nazikliğinden ve zarifliğinden dolayı ayă̆ının tabanını yere koymă̆a alışmamış olan zarif ve nazik kadının gözü koynundaki kocasına karşı ve oğluna karşı ve kızına karşı ve rahminden yeni doğan çocuğa karşı ve doğuracă̆l çocuklarına karşı kötü olacak. "»1

Birçok araştırmacı, Tekvin 16'da yer alan Abram, karısı Saray ve cariye Hacar arasında geçen olayın dolaylı olarak kıskançlığın ve fesatlığın kem gözle bağlantısını yansıttığını düşünmektedir ${ }^{82}$. Öykü, Eski Yakındoğu geleneğine uyan çocuk doğuramayan Saray’ın, Abram'ın soyunun devam edebilmesi için cariyesi Hacar'1 kocasına sunmasıyla başlar. Saray’ın iddiasına göre Hacar, hamile olduğunu öğrendikten sonra kendisine kötü bakar ve küstah davranmaya başlar. Bunun üzerine Saray buna katlanamaz ve Hacar'ı hor görür ve ona aşağılayıcı bakışlar atar. Bu davranışların üzerine çöle kaçan Hacar, kendisini teselli eden, kendisinin ve oğlunun kaderini belirleyen Yahve'nin meleklerinden biriyle karşılaşır ve Saray'ın yanına geri döner ${ }^{83}$.

Bu öykünün alt temasında Saray'ın Hacar'ın hamile kalmasına duyduğu öfke ve kıskançlığın yattığı düşünülmektedir. Saray hem kendisi çocuk doğuramadığından hem de verasetini bir köylü ve köylünün oğluyla paylaşma düşüncesi nedeniyle büyük bir kıskançlık hissine kapılmıştır. Bu fesatlık ve kıskançlık içinde Hacar'ın kendisine kötü gözle baktığını ileri sürerek aslında kendi kötü bakışı ve fesatlığıyla ondan kurtulmak istemiştir.

İsrail halkının, gözün sembolik yönlerinden fesatlığa ve diğer negatif düşüncelere bağlı olarak ortaya çıktığı kötü yönüne inandıkları (bazıları dolaylı olarak anlatılmasına rağmen) Eski Ahit’te açıktır. Bu kötü gözden korunma yöntemlerinin arasında Mezopotamya ve Mısır'dakine benzerlik gösteren muskaların kullanıldığı görülmektedir. İsrail'de koruyucu muska olarak kullanılan objeler genellikle küpe, yüzük ve kolye gibi farklı şekiller verilmiş altın ya da gümüş takılardan oluşmaktadır ${ }^{84}$. Bunların bazılarının hilal şeklinde tasarlandığ yine dolaylı olarak Eski Ahit’ten öğrenilmektedir: “Zebahla Tsalmunna dediler: Sen kalk da bizi vur; çünkü adam gücü nasıl olsa öyledir. Ve Gideon kalktı ve Zebahı ve Tsalmunnayı öldürdü, ve develerinin boyunlarında asılı olan hilallerini aldı... "85

Elliott'un belirttiği gibi, Eski Ahit'in pek çok bölümünde bahsedilen mavi rengin sembolik olarak bu halk için önemli olduğu ve koruyucu özellik taşıdığına inandıklarını düşünmek,

81 Tesniye 28: 54/56-57.

82 Louis Ginzburg, The legends of the Jews, The Jewish Publication Society of America, Philadelphia 1913, s. 239; Rivka Ulmer, The Evil Eye in the Bible and in Rabbinic Literature, Ktav Publishing, Hoboken, NJ 1994, s. 112-113; Robert Alter, Genesis: Translation and Commentary, W. W. Norton, New York 1996, s. 68; Zacharias Kotze, "A Case of the Evil Eye in Genesis 16:4-5: A Social-Scientific Serspective", HTS Teologiese Studies/ Theological Studies, 73 (3), 2017, s. 5.

83 Tekvin 16: 1-15.

84 İşaya 3: 19-24.

85 Hâkimler 8: 21. 
referansları değerlendirince oldukça akla yatkın bir yaklaşımdır ${ }^{86}$. Baskın renk olarak maviden bahseden bölümler incelendiğinde okuyucu, bu rengin sembolik olarak koruyucu olduğu yorumuna dolaylı olarak ulaşabilir ${ }^{87}$. Mavinin gökyüzü ile olan bağlantısından dolayı, İsrail'de de tıpkı Mezopotamya'da olduğu gibi koruyucu bir nitelik taşıdığı inancının varlığı söz konusu olabilir.

\section{2. İlahi ve Koruyucu Göz İnancı}

Genel olarak Eski Yakındoğu dünyasında düalizm bağlamında sembolik olarak göze yüklenen olumlu yön her şeyi gören, her yerde bulunan, kutsallı̆̆ 1 ve adaleti temsil eden ilahi bir güç ile özdeşleştirilmiştir. Gözün, ilahi bir varlıkla ilişkilendirilerek pek çok farklı türde mitolojik hikâyede ve görsel sanatta betimlendiği görülmektedir. Çoğu dini inançta numinous güç ve güçler gökyüzünde ikamet ederler. Özellikle Mezopotamya ve Mısır dinlerinde gökyüzünün görkemi, kutsiyeti, gök cisimlerinin ilahlaştırılması ve tüm dünyaya hâkim oldukları düşüncesi sayesinde gökyüzünden her şeyi gören ilahi göz sembolizminin varlığı oldukça akla yatkındır. Tek tanrılı bir inanç sistemine sahip olan İsrail halkı için ise göz, tek tanrı RABBİN her şeyi bilmesi, adaleti ve tek olmasıyla ilişkilidir. Gözün tanrılarla ilişkilendirilmesi, göze tapınım anlamına gelmemelidir. Ulmer'in belirttiği gibi, dini bir kontekst içerisinde yer alan göz, nadiren fiziksel anlamlar barındırırken çoğu yerde bambaşka simgesel anlamlarla donatılmıştır ve göz, tapınılan bir nesne değil ilahın temsil edildiği şeylerden biridir ${ }^{88}$.

\section{a. Mezopotamya}

Mezopotamya dininde çok fazla olmamasına rağmen her şeyi gören tanrı imgesinin izlerine yazılı metinlerde ve göz şekli ile tasarlanmış görsellerde rastlanmaktadır. Mezopotamya'da göz sembolizminin düalist yaklaşımındaki pozitif yanı Mısır'da olduğu kadar yaygın bir inanç değildir. Buna rağmen, belirli Mezopotamya tanrılarına atfedilmiş her şeyi gören göz simgeselliğinin varlığı yok sayılmamalıdır. Her şeyi gören ve her şeye hâkim olan göz ve tanrı eşleştirmesi elbette diğer tanrılara kıyasla astral tanrılarla ve her yerde var olabilen hava tanrısıyla daha çok ilişkilendirilmiştir. Bunların arasında gök tanrısı An, ay tanrısı Nanna/ Sin güneş tanrısı Utu/Šamaš ve hava tanrısı ENLİL yer almaktadır. Bunların dışında, tüm Mezopotamya'da panteonun en üst sırasına geçen Babil'in baş tanrısı Marduk'un da her şeyi gören gözle ilişkilendirilmesine Enuma Eliš' de ${ }^{89}$ rastlanmaktadır.

86 Elliott, a.g.e., vol. III, s. 117.

87 Çı1kış 24: 10., Çıkış 26:31., Çıkış 28:33-35., Çıkış 28:5., Sayılar 4:11-12. Sayılar 15:38-39.

88 Ulmer, a.g.m., s. 2.

89 Babil Yaradılış Destanı, Enuma Eliš Akadça'da 'gökyüzünde iken, vaktiyle yukarıda' anlamına gelir ve adını da destanın başlangıç sözcüklerinden alır. Ninova'daki kazılar esnasında, Asurbanipal'in Kütüphanesi'nde keşfedilmiş ve bin yüz satırdan oluşan yedi adet kil tablet üzerine çivi yazısıyla kaydedildiği bilinmektedir. Enuma Eliš, yapı açısından tanrıların, yeryüzünün, gökyüzünün, mevsimlerin, takımyıldızlarının ve tüm insan yaşamının oluşmasını açıklayan bir teoloji, bir kozmogoni ve bir kozmolojidir. Destanın özeti, detayları ve tamamı için bkz. Alexander Heidel, Enüma Eliş Babil Yaratılış Destanı, Ayraç Yayınevi, Ankara 2000. 
Her şeyi gören kavramının en belirgin örneklerinden birine kral Lipit-İštar'a yazılmış bir ilahide rastlanmaktadır: "AN, kimsenin kaçamadığ yıldızl göklerin tanrısı" "90 Gökyüzünün tanrısı yeryüzünde olan her şeyi görebilen ve böylece her şeyi bilen bir pozisyonda yer almaktadır. Aynı metinde hava tanrısı Enlil'in de gözlerinin gücünden bahsedilmiştir: "Senin gözlerin yorulmaz. "91 Mezopotamya'nın hava ve rüzgâr tanrısı olarak Enlil'in, yeryüzünde dolaşarak her şeye hâkim olabildiğine inanılmaktadır. Ay tanrısı Nanna/Sin ve güneş tanrısı UTU/Šamaš da biri gece diğeri gündüz olmak üzere gökyüzünden her şeyi gören tanrılar arasındadırlar ${ }^{92}$. Šamaš, gökyüzünde aydınlık yaratarak her şeyi görebiliyor olmasından dolayı doğruluğun, adaletin ve haklılığın tanrısı olma niteliklerini kazanmıştır. Nanna/Sin'in ise gece karanlığı aydınlatarak ve bir göz gibi ortaya çıkarak sınırların koruyucusu olduğuna inanılmıştır ${ }^{93}$.

Yazılı metinlerin dışında Mezopotamya'da göz sembolizminin yer aldığı diğer kaynaklar silindir mühürler ve yukarıda da bahsedilmiş olduğu gibi koruyucu olarak düşünülen göz şekilli muskalar ya da adak objeleridir. Mezopotamya sanatının en etkileyici eserlerinden biri, bölgede yaygın olarak keşfedilen silindir mühürlerdir. Bu mühürler arasında grafiksel olarak Mezopotamya inanç sistemini çeşitli göz sembolüyle betimleyen örnekler yer almaktadır. Mühürlerin tasarımları, onu yapanların fikirlerini yansıtır ve böylece yüzyıllar boyunca kültür ve inanç sisteminde ilah kavramını açığa çıkartırlar. Örneğin; bir silindir mühürde altı göz, ok ve yayla kabartılmış iki avcı resmedilmiştir. Seawright'ın belirttiğine göre, resmedilen bu altı göz, tanrıları temsil etmektedir ve bu sahnenin alt temasında her şeyi gören bu gözler avcıları korumaktadır ${ }^{94}$.

\section{b. Misır}

Mısır medeniyetinin inancında göz sembolizminin yeri, diğer toplumlardakinden çok daha farklı ve önemlidir. Bu toplumun teolojisinde gözün ilahi gücü ve yeri sadece her şeyi gören göz tanımlamasıyla açıklanamayacak kadar karmaşık ve özeldir. Günümüz insanı için yalnızca hikâyelerden ibaret olan, ancak eski toplumların tamamen gerçekliğini ve inancını yansıtan mitoloji, Mısır'daki göz sembolizminin bu denli önemli olmasının temel nedenidir. Horus ve Seth arasındaki çekişme, Ra'nın gözünün ortadan kaybolması, gözyaşıly insanların yaradılışı ve bunun gibi bu toplumun inancını yansıtan bazı öyküler, gözün simgesel yapısını şekillendirerek neredeyse tüm ikonografilerde yer almasını sağlamıştır.

Mısır'da ilahi göz kavramı ya da gözün ilahi âlemdeki yeri oldukça kapsamlıdır ve öncelikle gökyüzünün en dikkat çeken iki gökcismi olan güneş ve ayla ilişkilendirilmiştir.

90 Raffaele Petazzoni, The All-Knowing God, Methuen\&Co. Ltd., London 1956, s. 77.

91 Petazzoni, a.g.e., s. 77.

92 Seawright, a.g.e., s. 28.

93 Seawright, a.g.e., s. 29.

94 Seawright, a.g.e., s. 45. Göz sembolünün Mezopotamya silindir mühürlerindeki diğer tasvirleri için bkz. Seawright, a.g.e. 
Mısır'da güneş tanrısı ve ay tanrısı kavramları, Mezopotamya'daki tanrı algısından oldukça farklıdır ${ }^{95}$. Mısır'da güneş, günün zamanına göre bile farklı isimlerle anılabilen ${ }^{96}$ ve genel anlamda Ra olarak tanımlanan tanrının gözle görülür sembolü olmuştur ${ }^{97}$. Mısır mitolojisinde çeşitli yaradılış hikâyeleri mevcuttur ve bunlardan birinde zaman kavramının, Ra'nın güneş biçiminde ufukta belirdiğinde başladığg anlatılmaktadır ${ }^{98}$. Ay ise Mısır inancında hallerine göre belirli isimlerle anılmış ve belirli ilahlarla bağdaştırılmıştır ${ }^{99}$. Mısır'ın karmaşık ilahi yapısı içerisinde güneş ve ay, ya Ra'nın sağ ve sol gözü ya Horus'un sağ ve sol gözü ya da Ra'nın sağ gözü güneş, Horus’un sol gözü ay olarak temsil edilmektedir ${ }^{100}$. Bunların dışında, Ra'nın kendisinden kaçan ve dişi bir tanrı olarak algılanan gözü ile ilgili hikâyeler de gözün Misır inancındaki ilahi yerini desteklemektedir.

\section{ba. Göz tanrıçası/Ra'nın Gözü}

Mısır'ın önemli ilahi figürlerinden biri olan Göz tanrıçasının, MÖ. birinci binyılda önem kazanmaya başladığ 1 mitolojik metinlerin tarihlendirmelerinden anlaşılmaktadır. Öteki tanrıları yarattığına inanılan Atum'un, Sanduka metinlerinde çocukları Shu ve Tefnut'u kaybettiğinden ve gözünü onları bulmaya gönderdiğinden bahsedilir ${ }^{101}$. Ancak Göz tanrıçası, ilk yaratıcı tanrı olarak bilinen ve güneşin batıdan kayboluşundaki temsili olan Atum'dan çok Ra’nın kızı olarak düşünülür ve “Tek Göz” tanrıça olarak tasarlanan güneş kursu ile ilişkilendirilir. Tek Göz tanrıçası ve güneş tanrısının kayıp çocuklarına dair pek çok farklı hikâye yer almaktadır. Bu hikâyelerden birinin devamında Shu ve Tefnut'un, Göz ile birlikte geri döndükleri zaman Göz’ün yerinde bir başka göz/güneş kursunun olduğu ve bu durumu kabullenmeyen Göz'ün dehşet saçtı̆̆ı anlatılmaktadır ${ }^{102}$.

95 Mezopotamya tanrılarından güneş ve ay tanrılarının Numinous güçleri, tecelli etmeleri ve evrendeki rollerinin detayları için bkz. Dilek, a.g.e., s.73-75. Mısır'da ay ve güneş gökcisimlerinin ve ilahi düzendeki yerlerinin detayı için bkz. Richard H. Wilkinson, Eski Mısır'ın Bütün Tanrı ve Tanrıçaları, çev. Ahmet Fethi Yıldırım, Alfa Mitoloji Yayınları, İstanbul 2016.

96 Ra: Güneş tanrısı, ışık, enerji ve yaşamın ana kaynağıdır. Atum/Atum-Ra: Atum ve Ra çoğu kez yaratanın ezeli ve güneşli yanının temsilcisi olarak kabul edilir ve her akşam yaşlanarak batan güneştir. Pinch, Misır Mitolojisi, s. 178, Wilkinson, a.g.e., s. 100. Ra- Horakhty doğudan yükselen muzaffer güneş çifte ufkun RaHorus'udur. Pinch, a.g.e., vol. III, s. 237. Khepri: Güneş tanrısının genellikle pislik böceği şeklinde resmedilen gündoğumu hali ve Ra'nın dört ana şeklinden biridir. Pinch, a.g.e., vol. III, s. 234; Budge, W., Antik Misır'da Ölüm Sonrası Yaşam ve Tanrılar, çev. Şebnem Duran, Lilith Yayıncılık, İzmir 2018, s. 91.

97 Pinch, Misır Mitolojisi, s. 275. Uzmanlar, Ra’nın gözü için Tanrıçanın Gözü veya güneş gözü (güneş kursu) tanımını yaparak onu ay gözünden (ay kursu) ayrıştırmışlardır. Pinch, Misır Mitolojisi, s. 154.

98 Budge, Antik Mısır'da Ölüm Sonrası Yaşam, s. 101.

99 Mısır'da güneşten farklı olarak tarihsel zamanda ay tapınılan bir güç olmamıştır. Ay, daha çok bağlantılı tanrı ve tanrıçaların simgesi ya da tezahürü olarak gösterilmiştir. Khonsu ve Thoth, yeni ay ve dolunay olarak ay ile bağdaştırılan önemli tanrılardır. Ancak, bu tanrıların dışında ayın ilişkilendirildiği en önemli tanrı Horus’tur ve ay, tanrısal şahin Horus'un sol gözü olarak kabul edilir.

100 Ulmer, a.g.m., s. 2-3; Elliott, a.g.e., vol. I, s. 121.

101 “Atum bir keresinde beni ve kız kardeşim Tefnut’u aramak için Tek Gözünü gönderdi. Ben karanlıkta ışık tuttum ve göz beni buldu." Pinch, a.g.e., vol. III, s. 109.

102 Bu versiyon Bremmer-Rhid Papirüsünde yer almaktadır. Hikâyenin sonunda öfkeli kızını yatıştırmak isteyen tanrı onu bir uraeus kobra yılanına dönüştürür ve onu alnına yerleştirir. Ulmer, a.g.m., s. 3; Pinch, Misır Mitolojisi, s. 109. 
Uzaktaki tanrıça olarak bilinen Ra'nın gözü kimi zaman güneş tanrısının dişi hali olarak tasvir edilirken aynı zamanda Ra'nın kızı olarak da bilinir. Ra'nın kızı olarak bu göz özellikle Bastet, Mut, Hathor, Tefnut ve Sekhmet gibi pek çok önemli tanrıça ile ilişkilendirilmiştir ${ }^{103}$.

Mısır'da göz sembolizminin diğer bir olumlu bağlantısı ise, gözyaşı ile insanın yaradılışı arasındaki ilişkidir. Mısır dilinde insanlar ve gözyaşı kelimelerinin sesteş olması oldukça dikkat çekicidir. Pinch'in belirttiği gibi 1130 numaralı Sanduka Metinlerinde her şeyin efendisinin tanrıları kendi terinden ve insanları da gözyaşından yarattığı açıklanmıştır ${ }^{104}$. Mısır edebiyatında teması tanrının gözyaşı ve insanın yaradılışı olan pek çok farklı hikâyeye rastlanmaktadır. Bu hikâyelerin bazıları Göz tanrıçasının öfkesinden dolayı üzülen yaratıcı tanrının gözyaşı döktüğünden ve insanların böyle oluştuğundan bahsederken diğerleri, Shu ve Tefnut'un dönüşünden dolayı tanrının akıttığı mutluluk gözyaşının insanlığı yarattığını söyler ${ }^{105}$. Bunların dışında yaratan için yazılan bir ilahide insanın iki kutsal gözden; güneşten ve aydan oluştuğundan bahsedilmektedir.

\section{bb. Horus'un Gözü/Wedjat/Ay}

Mısır'da göz sembolizminin pek çok ilahi yönünün bulunduğundan bahsedilmişti. Bunların en önemlilerinden biri, çoğu görsel sanatta yer alan, koruyucu özelliği olduğuna inanılan ve ay ile de bağdaştırılan ${ }^{106}$ Horus'un sol gözüdür (wedjat). Mısır edebiyatında Horus'un sol gözünün Seth tarafından sakatlanması ve Thoth tarafindan onarılmasına dair pek çok farklı anlatım yer almaktadır. Bu efsanelerde iyileştirilmiş ve bütün hale getirilmiş göz wedjat olarak tanımlanmaktadır. Bu göz tanrılara, kraliyet mensuplarına ve ölülere sunulan adaklar dâhil ilahi düzenin her yönünü temsil etmektedir. Bu da Mısır'da kötülüklerden korunmak için kullanılan nesneler arasında en önemlileri arasında yer almasını sağlamıştır ${ }^{107}$. Sonuç olarak Horus’un gözüne yüklenen kutsallığın genel çerçevesi Seth ile arasındaki bitmeyen savaşı anlatan, iyi ve kötü dengesini açıklayan bu mitolojik hikâyeler sonucunda oluşmuştur.

103 Mısır tanrı geleneğinde önemli tanrı ve tanrıçaların çoklu kimlikleri olduğu görülmektedir. Bu ilahlar tekil bir kimlik sergilemenin yanı sıra birden fazla role sahiplerdi. Bu durum en çok güneş tanrısı Ra'da karşımıza çıkmaktadır. Ra bir nevi sıfat haline gelerek diğer tanrıların ululuğunu arttırarak işlev yelpazelerini genişletmekteydi. Wilkinson, a.g.e., s. 30. Bu konuyla bağlantılı olarak Pinch, bir tanrının rolünün çoğu kez çift ya da grup halinde saptanabileceğini belirterek Göz'ün Tefnut bağlantısını açıklamıştır ve Tefnut, Maat ile eşleştiğinde yaratanın hırçın ve uysal kızlarını temsil ettiğini öne sürmüştür. Pinch, a.g.e., vol. III, s. 155. Bu noktada Mısır'da var olan düalizmdeki denge unsuru yine dikkat çekmektedir; Mısır'da güneş gözünün öfkesinin adalet ve gerçeği temsil eden Maat ile dengelenmediğinde dünyaya kaosun egemen olacağına inanılmıştır. Ra’nın gözünün eşleştiği tüm diğer tanrılar için bkz. Pinch, a.g.e., vol. III; Wilkinson, a.g.e.

104 Pinch, Mistr Mitolojisi, s. 112.

105 Pinch, Misir Mitolojisi, s. 113.

106 Pinch'e göre Dolunay Osiris'in bütün bedenini ve oğlu Horus’un gözünü temsil etmektedir. Ay küçülürken Osiris'in bedeni ve Horus’un gözü de bölünür. Bu durumda kötülük üstün gelmiş gibi görünse de ay yeniden büyür ve iyi gücün iki simgesi yeniden bütünleşir. Bunun yanı sıra ay tutulması da Seth'in Horus'un gözünü yutması ve onu kusmak zorunda kalması olarak algılanır. Pinch, Mısır Mitolojisi, s. 149. Burada yine Mısır'daki iyilik ve kötülük düalizminin dengesini gösteren işaretler yer almaktadır.

107 Ulmer, a.g.m., s. 3; Elliott, a.g.e., vol. I, s. 124; Pinch, Misır Mitolojisi, s. 200. 
Horus'un gözü bir insan gözü ve kaşı ile bir şahinin bazı yüz özelliklerinin birleşimidir. Gözün altı bölümünden oluşan aritmetik olarak betimlenmiş bu sembolik şekil üzerine pek çok araştırma yapılmış ve resim yazısındaki standart şeklin tıp, ölçü birimleri ve diğer pek çok bilimsel alanda değeri olduğu ortaya koyulmuştur ${ }^{108}$. Wedjat aynı zamanda pek çok Mısır ritüelinde hem şekilsel olarak hem de mitolojik gerçeklikle ilişkilendirilerek rahiplerin kullandığ1 ritüel sözlerde de yer almıştır. Bunların arasında Mısır'ın Ağız Açma törenleri de bulunmaktadır109. "Iç̧indeki çürüme sana dokunmayacak. Sana Horus'un Gözü'nü ve yüzün onunla doldu.”... Ağzını ve dişlerini yerlerine yerleştirdim. Selam sana Osiris. Horus'un Gözü ile ağzını açtım. " 110 Cemaatle yapılan cenaze sunuları duasında da Horus'un Gözü’nün önemi göze çarpmaktadır. Burada yüz elliye yakın adak ve sunu görülmektedir. Rahip sözleriyle her bir nesneyi firavunun ruhu tarafından emilebilen ya da kullanılabilen ve ona ölümden sonraki yaşamda varlığını sürdürmesi için yardımcı olan, yaşam veren Horus'un gözüne dönüştürürdü ${ }^{11}$. Cenaze Töreni duasının 37. ve 62. günlerinde de Horus'un gözlerinden bahsedilmektedir ${ }^{12}$.

\section{c. İsrail}

Eski Ahit’te göz kelimesi için kullanılan İbranice ayin terimi pek çok olumlu değere hitap etmektedir ${ }^{113}$. İsrail halkının dini inancında Tanrı'nın fiziksel tasviri, çok tanrılı dinlerde tapınılan putları anımsattığ 1 ve tek Tanrı'nın gizemini ya da kutsiyetini bozabileceği için yasaklanmıştır. "Kendin için oyma put, yukarda göklerde olanın, yahut aşağıda yerde olanın, yahut yerin altında sularda olanın hiç suretini yapmayacaksın." 114 Bundan dolayı Eski Ahit'te ilahi göz sembolizminin yalnızca mecazi yansımaları görülmektedir. Eski Ahit'te yer alan göz sembolizminin olumlu yansımaları, genel çerçevede her şeyi gören, adaleti simgeleyen, bilginin, gerçekliğin, doğruluğun, ahlaki değerlendirmenin, iletişimin, kavrama yetisinin ve anlamanın ilahi gücüdür. Bahsedilen bu anlamlar, ilahi göz ile bağlantılı olan metaforik yaklaşımları gösterir.

108 Detaylı bilgi için bkz. Christian Irigaray, "The Eye of Horus: An Initiation into Pharaonic Wisdom" https://www. academia.edu/33249747/The_Eye_of_Horus_An_Initiation_into_Pharaonic_Wisdom_Parts_I-III, 2017, s. 1-20.

109 Hanedanlıklar döneminde bu tören firavunun heykeline uygulanırdı. Heykelin dudaklarının üzerine peskef denilen bir aletin konmasıyla gerçekleştirilirdi. Bundaki amaç, ölü firavunun ağzını saran sargıların kesileceğine ve ağzının açılarak serbest kalacağına inanılmasıydı. Daha sonraki dönemlerde ise Ağız Açma Ritüelleri çok daha geniş kapsamlı yapılmaya başlanmıştır. Wallis Budge, Antik Mısır Edebiyatı, çev. Selin Albayrak, Atlantis Yayınevi, İzmir 2016.

110 Budge, Antik Misır Edebiyatı, s. 30-31.

111 Budge, Antik Misir Edebiyatı, s. 33.

112 37. Gün: “Beyaz ve Siyah, Horus'un iki Gözü’nün sahibi oldun ve onlar senin yüzünde olduklarında yüzünü aydınlatırlar.” 62. Gün: Onu sahip olduğun bir ruh (Khu) yap ve kendi bedeninin efendisi olmasını sağla, gözlerini aç, bütün ruhların onu görmesini ve onun adını duymasını sağla. Bak işte, Horus'un gözü sana getirildi, çünkü o senin huzurunda olabilsin diye senin için ele geçirildi.” Budge, Antik Misır Edebiyatı, s. 34.

113 Ayin kelimesi, hem göz hem iyi hem de kaynak anlamlarına tekabül etmektedir. Ulmer, a.g.m., s. 6., Elliott, Eski Ahit’te yaklaşık 886 kez göz kelimesinin geçtiğini belirtmiştir. Elliott, a.g.e., vol. III, s. 14.

114 Çııış 20:4. 
“Şerirleri ve iyileri gözeterek, RABBİN gözleri her yerdedir.”115 “Çünkü RABBIN gözleri, yürekleri kendisi ile bütün olanlar uğrunda kuvvetli olduğunu göstermek için bütün yeryüzünde firlanır." "116 "Fakat RAB Samuele dedi: Onun görünüşüne ve boyunun uzunluğuna bakma; çünkü onu reddettim; çünkü RAB insanın gördüğü gibi görmez; çünkü insan yüze bakar, fakat RAB yüreğe bakar.” 117 "Eğiteceğim seni, gideceğin yolu göstereceğim, öğ̈̈t vereceğim sana, gözüm sendedir.” 118 “Çünkü küçük işler gününü kim hor görür? Çünkü şakulü Zerubbabelin elinde görerek bu yediler sevinecekler; onlar RABBIN gözleridir; o gözler ki, bütün yeryüzünde gezinmektedirler." "119 RABBIN gözleri doğru kişilerin üzerindedir, kulakları onların yakarışına açıktır.” 120 “Ama RABBIN gözü kendisinden korkanların, Sevgisine umut bağlayanların üzerindedir.” "'21 “Çünkü insanın yolları RABBIN gözü önündedir; ve onun bütün yollarını tartar." ${ }^{122}$ RABBINN gözleri bilgiyi korur; fakat hain adamın sözlerini alt üst eder $^{123}$.

Eski Ahit’te yer alan bu alıntılardan da net bir şekilde anlaşıldığı üzere, İsrail halkının inandığı bu dinde İlah ile bağlantılı simgesel göz her şeyi bilen, gören, anlayan, yargılayan anlamlarını içermektedir. Tanrı'ya ait ayrı bir göz kavramından ya da tanrıyı simgeleyen herhangi bir tecelliden bahsedilmez. Bu bağlamda göz kelimesinin sadece metaforik kullanımları ön plana çıkmıştır.

\section{Sonuç}

Düalizm olgusunun Eski Yakındoğu toplumlarında göz sembolizmine yansımaları incelendiği zaman bu üç toplumda da kem göz ve ilahi göz olmak üzere ikili sembolik göz inancının varlığı ortaya çıkmıştır. Her toplumun kendisine ait inancı, kültürü, evren algısı ve dünya görüşü olmasından ötürü, düalist göz sembolizmine yaklaşımları da bazı noktalarda benzerlik gösterirken bazılarında farklılaşmıştır. Antik Mezopotamya ve İsrail toplumlarında düalizmin dini etkisinin net bir şekilde hissedildiği tespit edilirken bu durum Antik Mısır toplumunda oldukça farklıdır. Bu toplumdaki inanç sistemi ve yaşam tarzı bir bütünlük ve denge içerisinde kendisini göstermektedir. Düalist yaklaşımda ele alındığında bu antik uygarlıkta iyi ve kötünün harmonisi dikkat çekmektedir.

Antik Mezopotamya toplumlarının dini inançlarının gerektirdiği belirli normlar, bölgede yaşayan insanların hayat tarzlarını ve evren algılarını da net çizgilerle ayırmıştır. İnançları

115 Süleymanın Meselleri 16: 4.

116 2. Tarihler 16:9.

117 1. Samuel 16:7.

118 Mezmurlar 32:8.

119 Zekerya 4: 10.

120 Mezmurlar 34: 15.

121 Mezmurlar 33: 18.

122 Süleymanın Meselleri 5:21.

123 Süleymanın Meselleri 21:12. 
gereği iyi ve kötünün dengesini kuramayan bu toplum, evreni oluşturan düalizm gerçekliğini yaşamlarının merkezi haline getirmiştir. Göz sembolizmi açısından değerlendirildiğinde, Mezopotamya toplumunun bu sembolik değere yaklaşımının daha çok olumsuz etkilere odaklanarak yine çift yönlü olduğu anlaşılmaktadır.

Antik Mezopotamya toprakları, çoğu uzmana göre kem göz inancının başladığı ve çevre bölgelere yayıldığ 1 yerdir. Bölgenin ilk yerleşen halkı olduğuna inanılan Sumerlerin bu inancı başlattığı, yaşattığı ve genişlettiği yazılı belgelerden ve arkeolojik verilerden anlaşılmaktadır. Mezopotamya toplumlarına göre, kem gözün en bilinen kaynağı her türlü kötülüğe sebep olan, gök tanrısı AN'ın yarattığı demonlardır. İnançları doğrultusunda kem göz, her türlü hastalık, kıtlık, felaket ve bunun gibi insan yaşamını ve geçimini etkileyen hasarlara sebep olmuştur. Mezopotamyalılar kem gözden kurtulmak için büyü, dua, ritüel ve en yaygın olarak göz şeklinde tasarlanmış muskalar kullanmışlardır.

Göz sembolizminin olumsuz yönünün baskın olduğu Antik Mezopotamya toplumlarında yaygın olmamakla birlikte tanrılarla ilişkilendirilen bir göz kavramından da bahsetmek mümkündür. Her şeyi gören ve adalet sağlayan göz kavramının daha çok gök tanrısı AN, ay tanrısı NANNA/Sin güneş tanrısı UTU/Šamaš gibi gökyüzü tanrıları ve panteonun en önemli tanrılarından ENLİL ve Babil döneminin baş tanrısı Marduk ile de ilişkilendirildiği görülmüştür.

Mezopotamya toplumundan farklı bir evren algısına sahip olan Misırlılar yaşamın daha çok olumlu yönüne odaklanmışlar ve tüm düalist yaklaşımları bir harmoni içerisinde değerlendirmişlerdir. Bu bağlamda göz sembolizminin de daha çok koruyucu tarafını vurgulamışlardır. Buna rağmen bu toplumda kem göz inancının varlığı, özellikle mitolojik hikâyelerinden ve ikonografilerinden anlaşılmaktadır. Horus mitleri ve wedjat gözün muska olarak kullanılması, bu inancın varlığının en net kanıtlarındandır. Misırlılar da Mezopotamyalılar gibi kem gözün sağlığa, aile birliğine ve özellikle çocuklara zarar verebilen bir tehdit olduğunu düşünmüşler ve aynı şekilde bu kötü güçten kurtulmak için dualar, büyüler ve muskalar kullanmışlardır. Bu toplumda kem göz algısının Mezopotamya'dakinden farkı, insanların da kem gözlerinden dolayı hasar yaratabildiklerine inanmalarıdır.

Koruyucu göz kavramının ve gözün ilahi dünya ile olan ilişkisinin en net olarak görüldüğü Antik Yakındoğu uygarlığı Mısır'dır. Öncelikle gökyüzünün en belirgin gökcisimleri olan güneş ve ay ile ilişkilendirilen göz, koruyucu niteliğini pek çok farklı versiyonu bulunan çeşitli mitolojik hikâyelerden kazanmıştır. Mısır edebiyatında Ra’nın gözü ve kızı olan Göz tanrıçasının kaçışı ve geri dönüşü, yaratıcı tanrının gözyaşları ile insanoğlunu yaratması, Horus'un gözünün Seth tarafından yaralanması gibi pek çok göz ile ilgili anlatı yer almaktadır. Bu hikâyelerin ortaya çıkış nedenleri ve dünyevi yaşamla bağlantıları, gözün Misır toplumundaki koruyucu rolünü ve önemini ortaya koymuştur. 
Tek tanrılı inanca geçtikten sonraki döneminin ele alındığı İsrail halkının düalizmin dini boyutuna yaklaşımında Mezopotamya'dakine benzer net ayrımlar dikkat çekmektedir. İsrail halkının dini inancı, Yahve'nin tek tanrı olarak kabul edilmesiyle başlar ve tüm dini gelişmeler öğretilerle birlikte Eski Ahit’te toplanır. Eski Ahit’te iyi ve kötü arasındaki düalizmden bahsederken iyilik açısından tek, kötülük açısından ise iki boyutlu bir kötülüğe değinmek mümkündür. İyilik kesin ve kati bir şekilde Tanrı'dan gelir. Kötülük ise RABBİN belirli sebeplerle yarattığı şeytan ve insanın doğuştan içinde yer alan kötü düşüncelerdir.

Bu dinin kutsal değerlerinden dolayı herhangi bir görsel betimlemeye izin verilmediği için göz sembolizmine dair tüm çıkarımlar en temel yazılı kaynak olan Eski Ahit’ten yapılmıştır. Bu kutsal kitapta gözün simgesel özelliklerini kapsayan olumlu ve olumsuz pek çok referans yer almaktadır. Öncelikle bu inançta kem göz kavramının insanların fesatlık ve kıskançlık gibi kötü duygularından kaynaklandığına dair kanıtlar yer almaktadır. Bu kutsal kitapta göze yüklenen olumlu sembolik özellikler metaforik şekilde kullanılmıştır. Bunların arasında ilk sırada Tanrı'nın gözü olarak her şeyi gören, bilen ve adaleti temsil eden ilahi göz sembolizmi yer almaktadır.

Hakem Değerlendirmesi: Dış bağımsız.

Çıkar Çatışması: Yazar çıkar çatışması bildirmemiştir.

Finansal Destek: Yazar bu çalışma için finansal destek almadığını beyan etmiştir.

Peer-review: Externally peer-reviewed.

Conflict of Interest: The author has no conflict of interest to declare.

Grant Support: The author declared that this study has received no financial support.

\section{Kaynakça/References}

Akalın, K.H., "Yahve ve Kenan Tanrıları”, Sosyal Bilimler Dergisi, XIV/1 (2012), s. 85-103.

Alter, R., Genesis: Translation and Commentary, W. W. Norton, New York 1996.

Aydın, F., “Bir Sessizliğin ya da Yhvh'nin Tarihi (YHVH'nin Telaffuz Edilmeme Olgusu Uzerine Bir Araştırma)", Usul, sayı 2 (2004), s. 103-128.

Bianchi, U., "Dualism”, ed. M. Eliade, The Encyclopedia of Religion, IV, Macmillan Publishing Company, New York 1987, 506-512.

Black J.- A. Green, Mezopotamya Mitolojisi Sözlüğü. Tanrllar Iritler Semboller, Köprü Kitapları, İstanbul 2017.

Borghouts, J. F., “The Evil Eye of Apopis”, The Journal of Egyptian Archaeology, vol. 59 (1973), s. 114-150. Bottéro, J. - S. N. Kramer, Mezopotamya Mitolojisi, çev. Alp Tümertekin, Türkiye İş Bankası Kültür Yayınları, İstanbul 2017.

Budge, W., From Fetish to God in Ancient Egypt, Oxford University Press, London 1934. 
, Amulets and Superstitions, with 22 plates and 300 Text Illustrations, New York 1978.

, Antik Mısır Edebiyatı, çev. Selin Albayrak, Atlantis Yayınevi, İzmir 2016.

, Antik Mısır'da Ölüm Sonrası Yaşam ve Tanrılar çev. Şebnem Duran, Lilith Yayıncılık, İzmir 2018.

Demirci, K., Eski Mezopotamya Dinlerine Giriş Tanrılar, Ritüel, Tapınak, Ayışı̆̆ı Kitapları, İstanbul 2013.

Dilek, Y., Eski Mezopotamya Dini Ritüelleri ve Kullanılan Objeler, Arkeoloji ve Sanat Yayınları, İstanbul 2019.

Durie, L. Dualism in Jewish Apocalyptic and Persian Religion, Yayınlanmamış Yüksek Lisans Tezi, Stellenbosch University, 2012.

Durkheim, E., Dini Hayatın İlkel Biçimleri, Ataç Yayınları, İstanbul 2005.

Eliade, M., Babil Simyası ve Kozmolojisi, çev. Mehmet Emin Özcan, Kabalcı Yayınevi, İstanbul 2002.

, Dinler Tarihine Giriş, çev. Lale Arslan Özcan, Kabalcı Yayınevi, İstanbul 2014.

Elliott, J. H., Beware the Evil Eye the Evil Eye in the Bible and the Ancient World, Vol 1: Introduction, Mesopotamia and Egypt, Wipf and Stock Publishers, Oregon 2015.

, Beware the Evil Eye the Evil Eye in the Bible and the Ancient World, Vol 3: The Bible and Related Sources, Wipf and Stock Publishers, Oregon 2016.

, The Evil Eye with modifications in The Ancient Mediterranean Social World: A Sourcebook, ed.

Zeba Crook, Eerdmans Publishing Company, Grand Rapids 2016.

Elworthy, F. T., The Evil Eye an Account of This Ancient Widespread Supersitition, Murray, London 1895.

Evans M. J., "The Middle Assyrian Period", Beyond Babylon: Art, Trade and Diplomacy in the Second Millenium B.C., ed. Joan Aruz, Kim Benzel, Jean M. Evans, The Metropolitan Museum of Art, New York Yale University Press, New Haven and London 2008.

Fohrer, G., History of Israelite Religion. S.P.C.K, London 1973.

Ford, J. N., "Ninety-Nine by the Evil eye and One from Natural Causes", KTU2 1.96 in its Near Eastern Context, Ugarit-Forschungen, say1 30 (1998), s. 201-278.

Frankfort, H., Ancient Egyptian Religion, Columbia University Press, New York 1948. , Kingship and the Gods, The University of Chicago Press, Chicago 1978.

Frazer, J. G., The Golden Bough: A Study of Magic and Religion, vol. I, Second Edition, Macmillan and Co. Ltd, London 1900.

Gershman, B., "The economic origins of the evil eye belief", Journal of Economic Behaviour and Organization, say1 110 (2015), s. 119-144, https://doi.org/10.1016/j.jebo 12.002.

Ginzburg, L., The Legends of the Jews, The Jewish Publication Society of America, Philadelphia 1913.

Goff, B. L., Symbols of Prehistoric Mesopotamia, Yale University Press, New Haven and London 1963.

Heidel, A, Enüma Eliş Babil Yaratılış Destanı, çev. İsmet Birkan, Ayraç Yayınevi, Ankara 2000.

Hornung, E., Kadim Mısır Ötedünya Kitapları, çev. Zehra Aksu Yı1mazer, Kabalcı Yayınevi, İstanbul 2006.

Irigaray, C., "The Eye of Horus: An Initiation into Pharaonic Wisdom”, https://www.academia.edu/33249747/

The_Eye_of_Horus_An_Initiation_into_Pharaonic_Wisdom_Parts_I-III, 2017, s. 1-20.

Işık, H., “Kitab-1 Mukaddes ve Kur'an’a Göre Şeytan”, Bozok Üniversitesi Ilahiyat Fakültesi Dergisi [BOZIFDER], say1 13 (2018), s. 35-74.

Jacobsen, T., Karanlı̆̆ın Hazineleri, çev. Sibel Erduman, Paris Yayınları, İstanbul 2017. 
Kotze, Z., "A Case of the Evil Eye in Genesis 16:4-5: A Social-Scientific Serspective", HTS Teologiese Studies/ Theological Studies, 73 (3), s. 1-6.

Kramer, S. N., Sumer Mitolojisi, çev. Hamide Koyukan, Kabalcı Yayınevi, İstanbul 2001.

Limmer A. S., The Social Functions and Ritual Significance of Jewelry in the Iron age II Southern Levant, Yayınlanmamış Doktora Tezi, The University of Arizona, Arizona 2007.

Lurker, M., The Gods and Symbols of Ancient Egypt, Thames and Hudson, London 1980.

Otto, R., Kutsal'a Dair, Altıkırkbeş Yayınları, İstanbul 2014.

Petazzoni, R., The All-Knowing God, Methuen\&Co. Ltd., London 1956.

Pinch, G., Magic in Ancient Egypt, University of Texas Press, Austin 1994. , Misır Mitolojisi, çev. Ekin Duru, Say Yayınları, İstanbul 2019.

Seawright, H. L., The symbolism of the eye in Mesopotamia and Israel, Yayınlanmamış Yüksek Lisans Tezi, Laurier University, Ontario 1988.

Tevrat, Dorlion Yayınları, Ankara 2018.

Thomsen, M. Louise. “The Evil Eye in Mesopotamia”, Journal of Near Eastern Studies, LI/1, The University of Chicago Press, 1992, s. 19-32.

Ulmer, R., The Evil Eye in the Bible and in Rabbinic Literature, Ktav Publishing, Hoboken, NJ 1994. , "The Divine Eye in Ancient Egypt and in the Midrashic Interpretation of Formative Judaism", Journal of Religion \& Society, vol. 5, 2003, s. 1-17.

Wasserman, N., "Seeing Eye to Eye: Concerning Two Incantations Against Lamashtu's Evil Eye”, Nouvelles Assyriologiques Bréves et Utilitaires, 1995, s. 61-70.

Watterson, B., The Gods of Ancient Egypt, Batsford Ltd, London 1984.

Wilkinson, R. H., Eski Mısır ’n Bütün Tanrı ve Tanrıçaları, çev. Ahmet Fethi Yıldırım, Alfa Mitoloji Yayınları, İstanbul 2016. 